Number 150 - January 2013

\title{
THE DARK SIDE OF FISCAL STIMULUS
}

Holger Strulik

Timo Trimborn

Georg-August-Universität Göttingen 


\title{
The Dark Side of Fiscal Stimulus
}

\author{
Holger Strulik* \\ Timo Trimborn**
}

First Version: February 2011. This Version: January 2013.

\begin{abstract}
Most of the discussion about fiscal stimulus focuses on the multiplier of government spending on impact. In this paper we shift the focus to the multiplier at the end, i.e. to the period in which a deficit spending program terminates. We show that recent time series analyses as well as economic models of different schools of thought predict that the multiplier turns negative before spending expires. This means that aggregate output at the time of expiry of fiscal stimulus is predicted to be lower than it could be without deficit spending. We set up a simple model that explains this phenomenon. Using phase diagram analysis we prove that the aggregate capital stock at the time of expiry of fiscal stimulus is lower than it would be without the deficit spending program. This fact explains why aggregate output is below its laissez faire level as well. We then calibrate an extended version of the model for the US and demonstrate how fiscal stimulus slows down recovery from a recession in the medium-run.
\end{abstract}

Keywords: fiscal stimulus, government spending, output multiplier, economic recovery. JEL: E60, H30, H50, O40.

\footnotetext{
* University of Göttingen, Department of Economics, Platz der Göttinger Sieben 3, 37073 Göttingen, Germany; email: holger.strulik@wiwi.uni-goettingen.de.

** University of Göttingen, Department of Economics, Platz der Göttinger Sieben 3, 37073 Göttingen, Germany; email: timo.trimborn@wiwi.uni-goettingen.de
} 


\section{INTRODUCTION}

The recent economic recession has resuscitated the discussion about the aggregate effects of fiscal stimulus and has inspired novel research on the output multiplier of government spending. While most of the literature is purely quantitative, we would like to continue a line of papers, which tried to make a general, theoretical point about the impact of government spending (Hall, 1980, Barro, 1981, Aiyagari et al. 1992, Baxter and King, 1993, Hall, 2009, Angeletos and Panousi, 2009). ${ }^{1}$

The earlier theoretical literature investigated whether the output multiplier of a temporary increase of government expenditure can exceed that of a permanent increase and whether and how the multiplier can be greater than one. We take up the discussion with a different twist and a novel insight. Shifting the focus from the impact multiplier to the moment of termination of an expenditure program we provide an explanation for the frequently observed phenomenon that aggregate output falls short of its laissez-faire level before a fiscal stimulus program expires.

Although the full story is more complex (see Section 3) the basic mechanism generating a negative multiplier at time of expiry is straightforwardly explained. When a deficit spending program is implemented, the added supply of government bonds exceeds the added need for savings. Consequently, households restructure their portfolio and save more in terms of bonds and less in terms of investment in private capital. This process continues as long as the deficit spending program is operative, implying that when the fiscal stimulus expires the aggregate capital stock is smaller than before. This in turn explains why output is lower than it could be without fiscal stimulus.

Identifying empirically the multiplier at time of expiry of a government shock turns out to be difficult for at least two reasons. First, by way of construction, VAR analysis assumes that government expenditure shocks phase out gradually. Consequently, VAR researchers usually focus on multipliers at impact, at peak, or at a certain time interval after the initial shock. Second, and perhaps more importantly, the literature has not yet converged towards a univocal method of identification of government shocks and thus provides different results for identical countries and periods of observation (for a survey, see Ramey, 2011a). Fortunately, Ramey (2011b) provided a comparison of results for the most popular identification methods, standard VAR and news-based identification (EVAR).

Figure 1, taken from Ramey (2011b), shows how US GDP responses to government spending under the alternative identification methods. Ramey's article focuses on the impact and early phase of fiscal

\footnotetext{
1 Some ideas and results of the present paper were disseminated in an earlier Discussion Paper, Strulik and Trimborn (2009).
} 
Figure 1: Output Response to Government Expenditure: VAR (Left) vs. EVAR
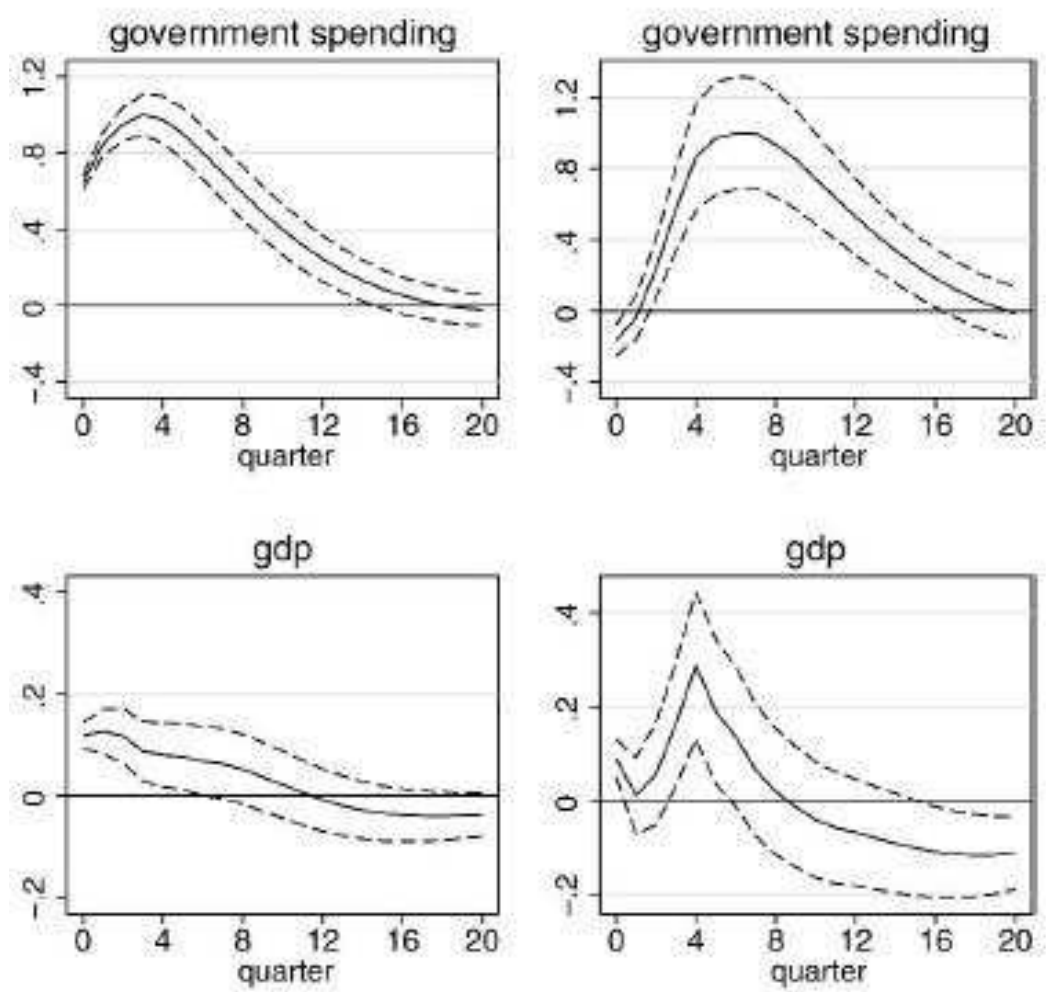

Left panel: shock identified by traditional VAR. Right panel: shock identified by news variables. Source: Ramey (2011b).

stimulus and explains the drastic difference between the impulse responses in this regard. From the perspective of the present paper, however, the visually arresting feature is that impulse responses do not differ much across methods at the end of the period of observation. Strictly speaking, a window of 20 quarters is too small to make inferences with significance because the upper confidence band has not yet crossed the zero line. But if we define as the end of fiscal stimulus the moment when the point estimate hits the zero line, we would conclude (in agreement with Ramey) that, irrespective of the method of shock identification, fiscal stimulus expires after about 4 years. The implied prediction is that GDP falls below zero (the laissez faire output) after about 3 years (left hand side) or 2 years (right hand side). In other words, GDP falls below laissez-faire level when the fiscal stimulus program is still active.

Given the uncertainty entailed by VAR estimates, in particular at longer lags (i.e. around what would be the "time of expiry" of spending plans with a given end), it is particularly useful that the undershooting behavior of GDP after a spending shock is supported by economic theory. Interestingly, the theoretical support appears to be independent from the underlying "school of thought". 
We next corroborate this claim by investigating how a government spending shock affects output in two popular business cycle models: The Baxter and King (1993) model and the Smets and Wouters (2007) model. The Baxter-King model is the seminal contribution investigating government behavior in the real business cycle framework and the Smets-Wouters model reached a kind of state-of-the-art status in the New-Keynesian community. In order to compare the effect of government spending on output for these two methodologically polar cases we take the benchmark calibration of both models as it was suggested in the corresponding original papers and apply the same government spending shock. $^{2}$

Our government spending shock follows the time path reported by Ramey (2011b) when war dates were used for identification. Basically, we assume that the spending shock follows the timing identified by Ramey (in the upper right panel of Figure 1 or Figure IV of Ramey, 2011b, respectively) but we measure it in percent deviation from steady-state output and normalize the peak at one percent. Measuring government shocks this way turned out to be useful in quantitative business cycles exercises (e.g. Cogan et al., 2010) because the impact of government spending on GDP can be immediately read off the impulse responses, as in Figure 2.

Furthermore we make two mild modifications in order to clearly establish our main point. First, we ignore that, according to Ramey, government spending is slightly negative initially and set instead spending to zero for an initial period of one quarter. This adjustment rules out distracting effects from negative spending. It means that the spending program is known for one quarter before it becomes active. Second, we assume that spending terminates after 20 quarters, i.e. when Ramey's point estimate hits the zero line (and then undershoots and fades out as time goes to infinity). We make this adjustment to better represent actual fiscal stimuli, which usually have a finite time of expiry. To summarize, spending starts in period 2, peaks after about 6 quarters, declines subsequently, and terminates after 20 quarters. The spending shock is shown by dashed lines in Figure 2.

Solid lines in Figure 2 show the response of GDP to the government spending shock predicted by the Baxter-King model (left hand side) and the Smets-Wouters model (right hand side). Both models predict a very different response of GDP on impact, a fact that is well known from the literature. A so far ignored phenomenon is that both models basically agree to what happens around the time of

\footnotetext{
${ }^{2}$ We implemented the Baxter-King model as calibrated in the original article ("Benchmark Model with Basic Government Purchases" from Table 1, p. 320) and solved for adjustment dynamics using the relaxation algorithm (Trimborn et al., 2008). For the Smets-Wouters model we used the model's implementation in the Dynare model database, see Wieland et al. (2012) and http://www.macromodelbase.com.
} 
Figure 2: Output Response to Temporary Government Expenditure: Neoclassical RBC (LEFT) vs. NeO-Keynesian DSGE (RIght)
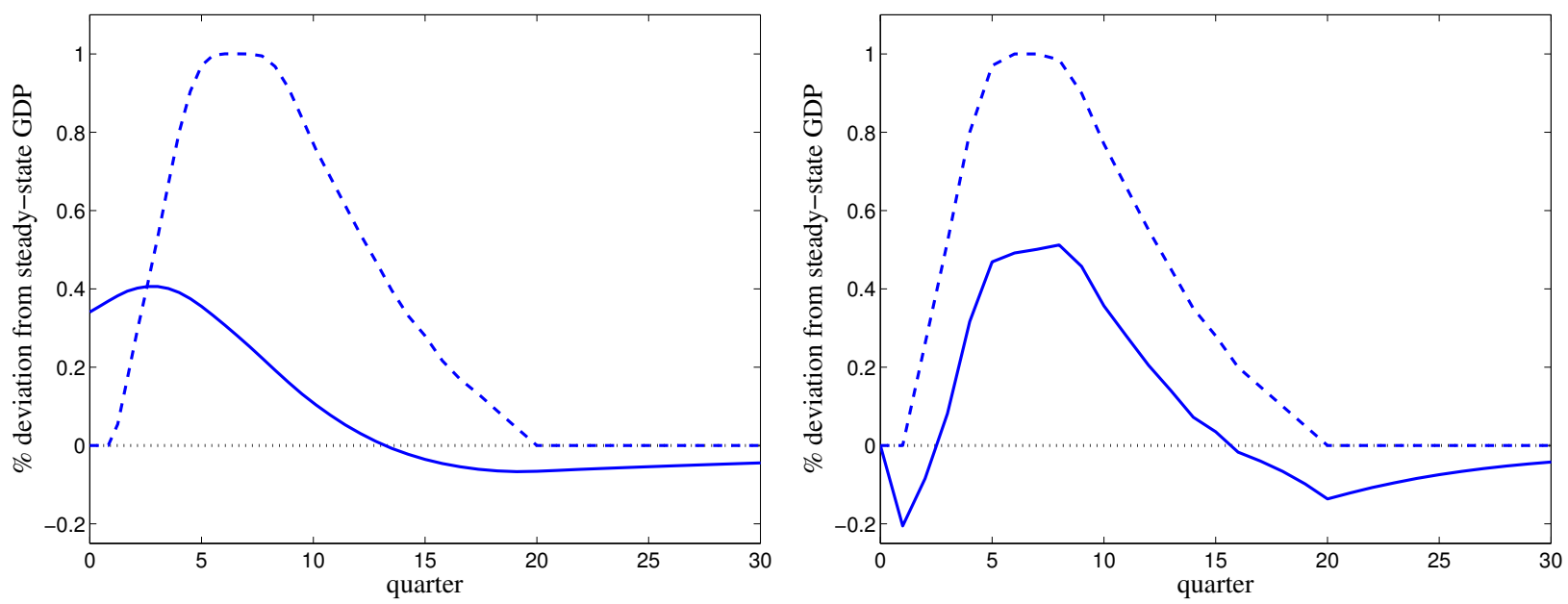

Left panel: Response of output (solid line) to the government expenditure program shock extracted from Ramey (dashed line) in the Baxter-King (1993) model. Right panel: Response of output (solid line) to the same shock (dashed line) in the Smets-Wouters (2007) model.

expiry of fiscal stimulus. GDP falls below its steady state level about one year before fiscal stimulus expires. From then onwards GDP recovers very slowly from below towards the steady state (the laissez faire level). In the Smets-Wouters case the fall below laissez faire level happens a bit later and the downfall is somewhat harder but these are small differences in comparison to the models' prediction for the initial phase of fiscal stimulus. The fact that both models basically agree at the time of expiry of the spending program is perhaps not surprising since in the medium run, with vanishing role for the various frictions, the "neoclassical features" dominate the performance of the new-Keynesian model. In the context of the present paper this means that the mechanism that turns the multiplier negative before spending expires seems to be very general. It is visible in the empirical impulse responses obtained with different methods and predicted by economic models of different schools of thought.

In order to explain the mechanism we set up a simple neoclassical model and use phase diagram analysis to prove that the aggregate capital stock has to be below its laissez faire value when a temporary deficit spending program expires. This fact, together with the observation that around the time of expiry of fiscal stimulus the initially positive effect on employment has almost vanished, explains why aggregate output (produced by capital and labor) is below laissez faire level as well. Naturally, we are not able to prove the generality of this result in a more complex new-Keynesian model because phase diagram analysis becomes impossible to perform. The evidence presented 
above, however, suggests that the mechanism is also operative in a new-Keynesian setting that allows for time-varying capital stock.

In Section 4-6 we set up an extended version of the model, calibrate it for the US, and show the mechanism "at work". In Section 5 we illustrate the quantitative implications of spending program initiated when the economy is situated at the steady state, i.e. we re-investigate the usual scenario in quantitative macro, here with special focus on the termination period of spending. In Section 6 we consider the case in which fiscal stimulus kicks in when the economy is in a recession. We investigate alternative assumptions about the severity of the recession, the size of the impact multiplier, and the scale and duration of the stimulus program and show how in each case the government spending program slows down economic recovery in the medium run. We do not address, however, a special phenomenon that has dominated the recent debate on the fiscal stimulus, the "zero lower bound" (see, for example, Christiano et al., 2011). We think that this omission can be justified, firstly, because we lack empirical evidence that the multiplier at expiry of deficit spending should be different in that case and, secondly, because we want to contribute to the understanding of a phenomenon which seems to occur with some generality rather than to elaborate on what could perhaps be different in a very special situation.

Aside from this constraint, our experiments show that results are quantitatively very similar independent from the cause of a recession. We model the cause of a recession, inspired by Chari et al. (2007), as either an efficiency wedge or a labor wedge. Chari et al. (2007) have shown that any actual business cycle can be reproduced by the standard real business cycle model with four wedges and that for the two examples investigated, the Great Depression and the 1982 recession, the efficiency wedge and the labor wedge account for essentially all of the fluctuations. ${ }^{3}$ We are thus confident that our result, which we can prove - constrained by mathematical complexity - only within the neoclassical framework, is much broader and covers many real world recessions and deficit spending policies.

\footnotetext{
3 Ohanian (2010) applies the methodology to the recession of 2007-2009 in high income countries. He finds that most of the recession is captured by an increasing efficiency wedge. A notable exception is the US, where the bulk of the recession is captured by an increasing labor wedge. There exists a large literature applying the neoclassical business cycle model to the Great Depression. An incomplete list includes Cole and Ohanian $(2002,2004)$, Kehoe and Prescott (2002, 2007), and Chari et al. (2002).
} 


\section{The Model}

In order to convey the intuition for our main result easily we begin with reconsidering the standard real business cycle model (King et al., 1988, King and Rebelo, 1999). Later on, in the numerical section, we add various taxes and frictions and investigate quantitative implications. In order to make inferences from phase diagram analysis the model is stated in continuous time. The economy is populated by a continuum of identical households of measure 1. Each household has preferences over private and public consumptions goods and leisure and maximizes intertemporal utility (1).

$$
\max _{c, \ell} \int_{0}^{\infty}\left(\log (c)+\beta \frac{(1-\ell)^{1-\gamma}-1}{1-\gamma}+\xi \frac{G^{1-\eta}-1}{1-\eta}\right) \mathrm{e}^{-\rho t} \mathrm{~d} t
$$

Here, $c$ denotes consumption of private goods, $G$ consumption of public goods (government purchases), and $\ell$ labor supply, $\rho$ is the time preference rate, $1 / \gamma$ the elasticity of intertemporal substitution for leisure, and $1 / \eta$ the elasticity of intertemporal substitution for consumption of public goods. The assumption of power utility for leisure nests three popular cases (Ludvigson, 1996). For $\gamma \rightarrow \infty$, labor is inelastically supplied, for $\gamma=1$ utility is logarithmic in leisure as frequently assumed in the real business cycle literature, and for $\gamma=0$ utility is linear in leisure as suggested by the indivisible labor model of Hansen (1985) and Rogerson (1988). The latter constitutes an important limiting case for the subsequent analysis since it implies the most elastic labor supply (an infinite Frisch elasticity).

Households face the budget constraint (2).

$$
\dot{a}=w \ell+r a-c-T,
$$

where $a$ denotes asset holdings, $w$ is the wage rate, $r$ the interest rate, and $T$ is a lump-sum tax paid to the government. As usual, the first order conditions for problem (1)-(2) provide the Ramsey rule (3) and the optimal trade-off between consumption and leisure (4).

$$
\begin{aligned}
\frac{\dot{c}}{c} & =r-\rho \\
w & =\frac{\beta c}{(1-\ell)^{\gamma}} .
\end{aligned}
$$


The government finances public goods expenditure $G$ and interest payments on debt $r b$ by taxes $T$ and new debt $\dot{b}$. Its budget constraint is given by (5).

$$
\dot{b}+T=G+r b
$$

Government bonds are held by households together with capital $k$ implying that total assets are defined by (6).

$$
a \equiv k+b
$$

A representative firm employs capital and labor and produces output according to a Cobb-Douglas technology $y=A k^{\alpha} \ell^{1-\alpha}$ where $A$ denotes aggregate factor productivity. At an equilibrium on the factor market, factor prices equal their marginal product such that $r=\alpha A k^{\alpha-1} \ell^{1-\alpha}-\delta$ and $w=(1-\alpha) A k^{\alpha} \ell^{-\alpha}$. At an equilibrium on the goods market, output is used for private and public consumption, and gross investment $\dot{k}+\delta k$, where $\delta$ denotes the rate of depreciation. This means that aggregate capital evolves according to (7).

$$
\dot{k}=y-c-\delta k-G \text {. }
$$

Finally we re-establish the intertemporal budget constraints for government and households. Integrating the flow budget constraint (5) and applying the no-Ponzi-game condition $\lim _{t \rightarrow \infty}$ $\mathrm{e}^{-\int_{0}^{t} r(u) d u} b(t) \mathrm{d} t=0$ we obtain (8) and integrating the flow budget constraint (2), applying the no-Ponzi-game condition $\lim _{t \rightarrow \infty} \mathrm{e}^{-\int_{0}^{t} r(u) d u} k(t) \mathrm{d} t=0$, using the capital market equilibrium (6), and inserting the government budget constraint (8) we obtain the household budget constraint (9).

$$
\begin{gathered}
0=b(0)+\int_{0}^{\infty}(G-T) e^{-\int_{0}^{s} r(u) d u} d s \\
\int_{0}^{\infty} c e^{-\int_{0}^{s} r(u) d u} d s=k(0)+\int_{0}^{\infty} w \ell e^{-\int_{0}^{s} r(u) d u} d s-\int_{0}^{\infty} G e^{-\int_{0}^{s} r(u) d u} d s .
\end{gathered}
$$

\section{The Government Spending Multiplier: Theory}

3.1. Intuition. In the tradition of the theoretical literature on the output multiplier of government spending we begin with a subsection that develops some preliminary intuition for our main result. With contrast to the earlier literature we shift the focus from the impact multiplier to the multiplier at the end of a deficit spending program and argue that capital stock and output fall short of their laissez-faire values when a fiscal stimulus program expires. 
In order to develop the intuition it is instructive to compare a temporary expenditure program with a permanent increase of government expenditure under the normalizing assumption that both policies entail the same present value $\int_{0}^{\infty} G e^{-\int_{0}^{s} r(u) d u} d s$. Obviously, this implies that expenditure is (much) higher for the temporary spending program during the periods in which spending is operative. Furthermore, suppose that both permanent and temporary expenditures are financed with the same time series of lump-sum taxes. This means for the temporary expenditure program that tax revenue during the spending phase is much lower than expenditure. The policy thus constitutes a deficitfinanced fiscal stimulus.

Recall that within the neoclassical setup a permanent increase of government expenditure increases long-run output permanently through the wealth effect, i.e. the long-run multiplier is positive. Focussing on a temporary expenditure program of the same present value is thus a disciplining device. It guarantees that our result that the multiplier turns negative before the expenditure program expires is not driven by the wealth effect. If we furthermore assume for a moment that labor is supplied inelastically, we can infer from (9) that the two expenditure programs reduce private consumption in present value terms by exactly the same amount.

Generally, if labor is supplied elastically, households react on the negative wealth effect not only by consuming less but also by supplying more labor since consumption and leisure are normal goods. More labor supply leads to a higher marginal product of capital and a higher interest rate. In case of a permanent rise of government expenditure, it is a well-known result that higher interest rates spur investment such that the capital stock raises gradually. Since this in turn depresses the interest rate, the economy moves towards a new steady-state at which the interest rate returns to its initial level (and equals the time preference rate) whereas both capital and labor are permanently higher than initially. The output multiplier is positive (see e.g. Aiyagari et al., 1992, Baxter and King, 1993).

Turning towards the temporary expenditure program, imagine for a moment that households choose the same response of consumption and labor supply as under the permanent program. Facing the same present value of government expenditure, households would indeed response in exactly the same way if interest rates stay constant. Actually, however, there is a dampening effect via the interest rate at work, but its magnitude is of second order such that the approximation error seems to be justified by the insight gained. The fact that households choose the same path of consumption and labor supply under both government expenditure policies implies that savings $(\dot{a})$ also follows 
the same path under both expenditure policies. Yet, households facing the temporary expenditure policy buy (much) more bonds $(\dot{b})$.

In order to understand why households restructure their asset holdings, recall that government expenditure is higher "per period" (per unit of time) for the temporary program because the same total expenditure in net present value terms is concentrated on a much smaller time span. Consequently, the government's demand for capital $(\dot{b})$ is also higher in each period for the temporary program. Formally, this can be seen by the government's budget constraint (5). On impact, taxes $T$ and interest on debt $r b$ are equal for both spending programs. The right hand side of the budget constraint (5) is the same for both policies. But because the government has to finance a higher level of expenditure $G$ when the temporary policy is operative, it has to issue more new debt $\dot{b}$ (left hand side of the budget constraint). Capital market equilibrium $(\dot{a}=\dot{k}+\dot{b})$ then requires that savings in terms of government bonds are higher and savings in private capital are lower than under the permanent expenditure policy. As a result, the private capital stock declines when the fiscal stimulus program is active. For the same reason, private investment and capital stock rise again after the termination of fiscal stimulus policy. Since the temporary policy has left all "fundamentals" unchanged, capital stock and output converge from below towards their initial steady-states. ${ }^{4}$

So far, capital supply was assumed to be the same for both spending policies such that the temporary expenditure program crowds out investment of $\dot{b}=G-T$; a crowding out which, by construction, does not occur under the permanent policy. In reality, fortunately, the implications of fiscal stimulus are somewhat less grim since there is a dampening effect at work. This is so because less private investment gradually reduces the capital stock, which in turn raises the return on capital and increases the incentive to save. This (second order) effect somewhat mitigates the negative effect of the temporary spending program on investment.

The result that capital stock is decreasing when deficit spending is active and increasing after it expired is explained by the equilibrium on capital markets and the fact that households follow a smooth path for savings. Capital market equilibrium requires that households buy additional

\footnotetext{
4 Note that - because of Ricardian equivalence - a similar mechanism would be at work if the expenditure program were financed by lump taxes. Higher taxes during the expenditure phase reduce households' disposable income and thus investment in private capital. Consequently the private capital stock is predicted to fall during the fiscal stimulus program.
} 
government bonds during the stimulus phase. ${ }^{5}$ Trying to keep savings smooth, households reduce private investment during the stimulus program in order to buy government bonds and expand private investment afterwards.

It should be noted that the negative response of consumption follows logically from the neoclassical framework but is not driving the result of negative multiplier at time of stimulus expiry. A positive response of consumption to fiscal stimulus, as found by some VAR analyses (Blanchard and Perotti, 2002) would, in fact, strengthen our result. Rising private and government consumption would imply, that even less of aggregate output is spent on private investment and that the capital stock is driven even further below steady-state level. Essential for our result is that private investment responds negatively to deficit spending. A negative response of investment seems to be a broadly observed phenomenon. It is reported by almost all empirical studies on fiscal stimulus, using different methods of identification (e.g. Ramey, 2011b; Blanchard and Perotti, 2002; Barro and Redlick, 2011).

Because the mechanism is so general, our conclusion holds true regardless of the state of the economy. If, for example, the economy is recovering from recession, the time path of wages and interest rates differs from those at the steady state. Naturally, net present value of wage income and net present value of government expenditure deviate compared to an economy that was initially at its steady state. But since the recession affects net present value in the same way for temporary and permanent expenditure policies, we expect that the magnitude by which consumption, labor supply, and investment differs between both spending policies will be roughly the same, no matter whether the economy is initially at its steady state or in transition.

3.2. Phase Diagram Analysis. In this subsection we prove that capital falls below steady-state level before a temporary government spending program expires, a fact that explains that output falls below steady state level as well. Here we consider an economy resting at the steady-state when the government expenditure shock occurs. Later on we investigate an economy driven far below its steady-state position (by efficiency- or labor-wedges) before deficit spending is implemented. The larger part of the proof uses phase diagram analysis to show that the capital stock falls short of its steady-state value at the moment of expiry of fiscal stimulus. We begin with setting up the phase diagram for the economy, which consists of the differential equations (3) and (6), labor

\footnotetext{
5 This would also hold in an open economy setting in which the rest of the world holds government bonds, since excessive supply of government bonds would be settled by demand from home and abroad. Only if capital supply from the rest of the world is infinitely elastic and independent from the home-country's level of debt, additional government bonds would exclusively be sold abroad and households would not have to change their portfolio.
} 
supply according to (4), and production $y=A k^{\alpha} \ell^{1-\alpha}$. Impulse responses for this economy can be represented in two-dimensional $c-k$ space as displayed in the two panels of Figure 2.

The steady-state is where the $\dot{c}=0$-isocline and the $\dot{k}=0$-isocline intersect. Along the $\dot{c}=0$ isocline, the capital labor ratio $k^{*} / \ell^{*}$ is determined by the time preference rate $\rho$. From (3), $\rho=$ $\alpha A\left(k^{*} / \ell^{*}\right)^{\alpha-1}-\delta$. In contrast to the familiar phase diagram of the neoclassical growth model with exogenous labor (see e.g. Barro and Sala-i-Martin, 2004) the $\dot{c}=0$-isocline is not vertical. It is downward sloping because consumption and leisure are normal goods and households supply more labor at lower levels of consumption (see (4)). The smaller the Frisch elasticity of labor supply, the steeper the slope of the isocline. In the limit, when labor is supplied inelastically, the isocline becomes a vertical line. On the other hand, if the Frisch elasticity of labor supply becomes infinite $(\gamma=0)$, the isocline becomes a horizontal line. Figure 2 shows an intermediate case. In the Appendix we derive the isoclines formally.

The $\dot{k}=0$-isocline is obtained by setting (6) to zero and solving for $c ; c=A k^{\alpha} \ell^{1-\alpha}-\delta k-G$. Here, the analysis coincides with the familiar textbook model: the isocline is increasing when the concave part stemming from the neoclassical production function is dominating and decreasing when the linear part stemming from depreciation is dominating. There exists a unique intersection of the isoclines and the resulting arrows of motion identify the equilibrium as a saddlepoint. The unique adjustment path after a change of government behavior is given by the movement along the stable saddlepath towards the steady-state.

It is instructive to begin the analysis with an inspection of adjustment dynamics after a permanent increase of government expenditure. Suppose the economy is situated initially at the steady-state A in Figure 2. More government expenditure reduces households' claims on output, $y-G$, and the $\dot{k}=0$-isocline shifts down. The $\dot{c}=0$-isocline remains unchanged. Because both consumption and leisure are normal goods, households respond to permanently lower income by consuming less and supplying more labor (the wealth effect). Higher labor supply increases the marginal product of capital and raises investment. The economy converges towards a steady state of higher aggregate capital, point $\mathrm{C}$ in Figure 2. Adjustment dynamics following a fiscal expansion are given by an instantaneous drop of private consumption, after which both capital and consumption increase along the stable saddlepath towards the new equilibrium. The economy jumps from A to B and then moves to $\mathrm{C}$. The transition path is indicated by dashed lines in both panels of Figure 2. 

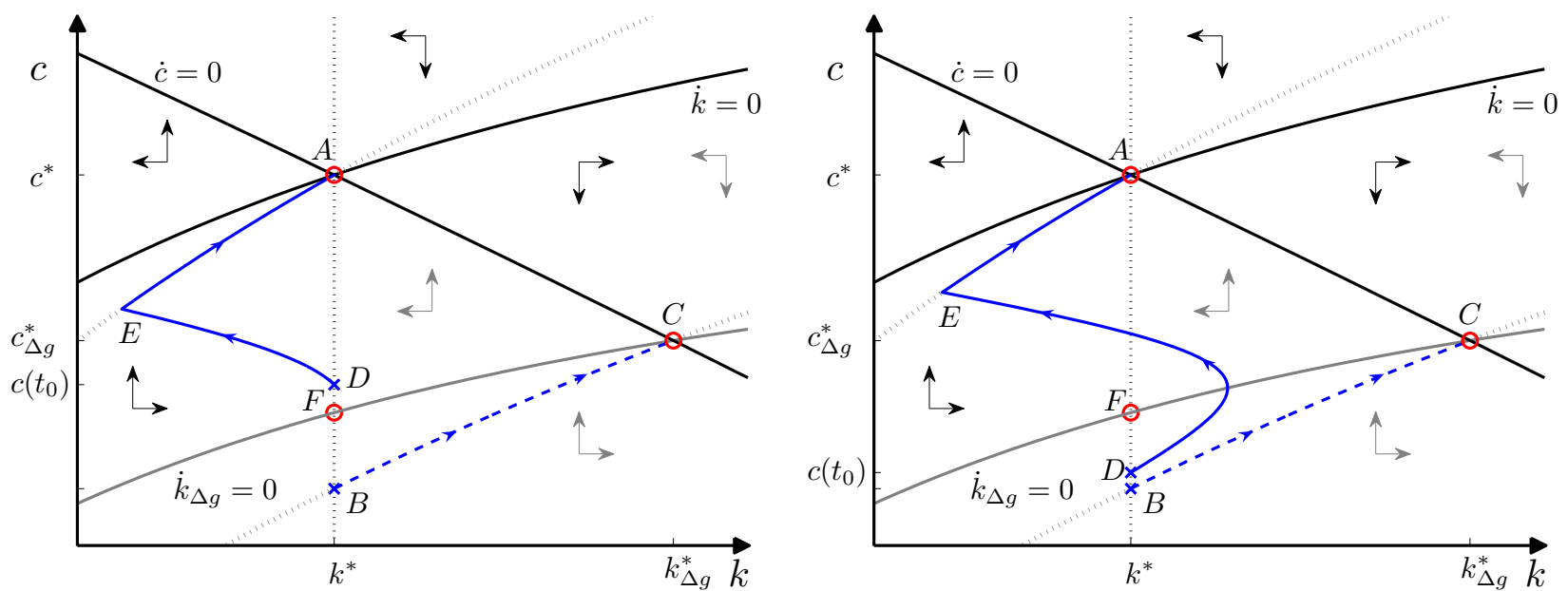

The black vector field is associated with the initial equilibrium A and the grey vector field is associated with the equilibrium assumed under higher government expenditure $C$. If the fiscal expansion is permanent, the grey vector field applies always. If the fiscal expansion is temporary, the grey vector field applies only when fiscal stimulus is active. When fiscal stimulus expires, the black vector field applies again.

Turning towards a temporary increase of government spending, we begin with assuming that $G$ increases unexpectedly at time $t_{0}$ and that the spending program is known to terminate at time $\tilde{t}^{6}$ Because households know in advance when the stimulus program ends, they adjust labor supply and investment already from $t_{0}$ onwards. Since there are no more surprises, there is only one jump of consumption and employment, namely at the moment when the economy is unexpectedly hit by the fiscal stimulus plan. Afterwards there are - by construction - no further shocks and any further jumps are ruled out by no-arbitrage . Formally, the first order condition for a utility maximum requires that the shadow price of capital, $\lambda=1 / c$, is continuous and thus consumption is continuous.

Because there cannot be any further jumps, and because any trajectory which is not starting on the stable saddlepath will never arrive at the steady-state, the economy has to be on the saddlepath and moving towards point A when deficit spending expires (i.e. at time $\tilde{t}$ ) and the "pre-shock" saddlepoint dynamics apply again. The fact that the state variable capital stock cannot jump implies that initial consumption after the shock $c\left(t_{0}\right)$ is found on a vertical line through point $k^{*}$. In Figure 2 this point is denoted by $\mathrm{D}$ on the dotted line through $\mathrm{A}$.

\footnotetext{
6 We could add more realism by assuming an announcement phase during which the spending program is known but not yet enacted and operative. This would increase the impact multiplier but would not affect the multiplier at time of expiry. We investigate announcement effects of fiscal policy by way of phase diagram analysis in Strulik and Trimborn (2010).
} 
In order understand adjustment dynamics note that as long as the expenditure program is active the grey arrows of motion, associated with steady-state C, apply. When the expenditure program expires, the black arrows of motion, associated with the initial steady-state A, apply again. The impulse response dynamics of consumption can thus be figured out by following the directions indicated by the grey arrow field for the period from $t_{0}$ to $\tilde{t}$. In doing so, it is straightforward to rule out any initial consumption levels above A and below B. In these cases the consumption path would never meet the stable saddlepath at time $\tilde{t}$. Within the remaining feasible range for $c(0)$, between point $\mathrm{A}$ and $\mathrm{B}$, we have to distinguish two cases, depending on the duration of the expenditure plan. These cases are shown in the left and right panel of Figure 2.

If the duration of the expenditure program is sufficiently short, households choose initial consumption above the $\dot{k}=0$-isocline associated with steady-state $\mathrm{C}$ (i.e. within the interval $\mathrm{AF}$ ) In this case, investment jumps down when the expenditure program starts and remains below steady-state level for the whole duration of the expenditure program. As a consequence, capital stock declines continuously until "fiscal stimulus" expires and the economy hits the stable saddlepath at a lower level of capital compared to the original steady state $k^{*}$. The resulting trajectory ADEA is shown by the solid line in the left panel of Figure 2 .

The case of a long-lasting but still temporary expenditure program is shown in the right panel of Figure 2. Here, households choose initial consumption below the $\dot{k}=0$-isocline associated with steady-state C (i.e. within the interval FB), implying that investment increases initially. Following the grey vector field, it is evident that the impulse response of investment soon turns negative (when the trajectory crosses the $\dot{k}=0$-isocline). Again capital stock falls below its initial steady-state while the expenditure program is still active and the economy hits the stable saddlepath in point $\mathrm{E}$ at a lower level of capital than $k^{*}$. The resulting trajectory ADEA for the second case is indicated by a solid line in the right panel of Figure 2 .

Intuitively, investment is above steady-state level initially because a longer spending program reduces household wealth more pronouncedly and triggers more labor supply. This in turn implies a relatively high marginal product of capital. At the beginning of the spending program, households respond to this incentive by saving more. After some time, however, the crowding out effect on investment becomes dominating and investment falls again below steady-state level. The main result that capital stock falls short of its steady-state level at the time of expiry is thus independent from the duration of fiscal stimulus. 
Real world fiscal stimulus, designed to shorten a recession, typically belongs to the first category (left panel). Numerical experiments with our calibration for the US from Section 4 show that expenditure programs shorter than 7.5 years lead to an immediate drop of investment. Moreover, for really long expenditure programs the initial phase of higher investment turns out to be relatively short. For example, for a 10 year expenditure program we find that investment falls below steadystate level after the first two years and stays there for the remaining eight years of "fiscal stimulus".

The fact that aggregate capital is below its steady-state level at the time of expiry of fiscal stimulus explains why output is below steady-state level as well. Output is produced from capital and labor such that, in principle, it could be above steady-state level if employment is far above steady-state level at that time and overcompensates the negative effect from aggregate capital. Such a behavior however would contradict the basic mechanism of the neoclassical growth model. In order to see this, note that the economy, at the point of expiry of fiscal stimulus is situated on the stable saddlepath and that, thus, the remaining transition towards the steady-state coincides with the transition of an economy starting with below steady-state endowment of physical capital. The basic feature of the neoclassical growth model is to explain why an economy less well endowed with capital per capita produces less GDP per capita. This feature is generally preserved when the neoclassical growth model is extended by elastic labor supply (morphing it into a business cycle model).

We acknowledge that our main result is not robust against any manipulation of the neoclassical model. But, following the logic explained above, these need to be manipulations that overturn the basic message of the neoclassical growth model, i.e. manipulations implying that, ceteris paribus, economies less well equipped with physical capital produce more GDP. Specifically, it can be shown that the integration of variable capital utilization into the model has the power to change our main result if utilization rates respond sufficiently strongly to changes of the interest rate. However, it can be shown that this is precisely the case when the model generates counterfactual growth dynamics (for a detailed investigation see Strulik and Trimborn, 2013).

\section{Calibration of an Extended Model}

In order to add more realism we augment the basic model by various taxes, an efficiency wedge and a labor wedge. We calibrate the model such that the multiplier of a permanent expenditure program as well as the impact multiplier of a temporary expenditure program is positive and - compared to empirical studies - of average size. We then show that GDP falls short of its laissez faire level 
before fiscal stimulus expires and we investigate for an economy that experiences a recession how fiscal stimulus slows down economic recovery.

Our modeling of recession-causing shocks is inspired by Chari et al.'s (2007) "equivalence results". Chari et al. show that a large variety of business cycle models is equivalent to a prototype model with wedges for efficiency, labor, investment, and government consumption. Moreover, they show that almost all business cycle dynamics of past US recessions can be accounted for by the efficiency wedge and the labor wedge. The efficiency wedge can (but need not) be motivated by input-financing frictions. The labor wedge can (but need not) be motivated by labor market frictions and sticky wages. Here we assume that a shock has driven either the productivity wedge or the labor wedge out of its steady-state and that the distortion returns gradually to its steady-state position.

4.1. Model Extension. For the efficiency wedge we assume that total factor productivity $A$ follows a first-order autoregressive process. Initially, at time 0 an exogenous shock has driven $A$ down by $A_{0}$. From the level $\left(A^{*}-A_{0}\right)$ factor productivity converges towards its steady state value $A^{*}$ at constant rate $\sigma$ as shown in (10). Linguistically, we address $\left(A^{*}-A(t)\right)$ as the efficiency wedge. The severity of a recession is thus increasing in the efficiency wedge. The labor wedge $\omega$ is introduced as a distortion of the marginal rate of substitution between consumption and leisure and the marginal product of labor beyond the "normal" distortion caused by labor income taxes. At the steady-state $\omega=0$. The severity of a recession is increasing in the labor wedge $\omega(t)$. From the initial value $\omega_{0}$ the labor wedge returns to zero at constant rate $\sigma$ as shown in (11).

$$
\begin{aligned}
& A(t)=A^{*}-A_{0} e^{-\sigma t} \\
& \omega(t)=\omega_{0} e^{-\sigma t} .
\end{aligned}
$$

Furthermore we integrate into the basic model a set of taxes. We assume that households pay taxes on interest income at rate $\tau_{a}$, on labor income at rate $\tau_{w}$ and on consumption at rate $\tau_{c}$. This implies that the household budget constraint modifies to (12) and the government budget constraint modifies to (13).

$$
\begin{aligned}
& \dot{a}=\left(1-\tau_{w}\right) w \ell+\left(1-\tau_{a}\right) r a-\left(1+\tau_{c}\right) c-T . \\
& \dot{b}+\tau_{w} w \ell+\tau_{a} r k+\tau_{c} c+T=r b+G .
\end{aligned}
$$


The households' first order conditions for maximizing (1) subject to (12) modify to (14) and (15) and aggregate capital accumulates according to (16).

$$
\begin{aligned}
& \frac{\dot{c}}{c}=r-\rho \\
& \frac{1-\tau_{w}}{1-\tau_{c}}(1-\omega) w=\frac{c \beta}{(1-\ell)^{\gamma}} \\
& \dot{k}=y-c-\delta k-g y-\omega w \ell=(1-g-\omega) y-c-\delta y .
\end{aligned}
$$

We define the output multiplier of government spending by comparing a scenario in which the government runs a deficit spending program with a laissez-faire scenario. Specifically, the multiplier is defined as the deviation of stimulated output from laissez faire output divided by the additional government spending, i.e. $\Delta Y(t) / \Delta G(t)$. This multiplier captures the effect of additional government spending on output at a particular point of time. Naturally, the multiplier is only defined as long as fiscal stimulus is active.

So far the literature has mainly focussed on the impact multiplier $\Delta Y(0) / \Delta G(0)$ or on the multiplier at times when additional government spending peaks. Here we focus on the multiplier at the end of a temporary spending program. This definition of a multiplier should not be confused with the definition of a present value multiplier, which measures the change of net present value of output in terms of net present value of government spending. The present value multiplier is generally a useful measure to assess the overall impact of a spending program. For the present paper, however, its use would conceal our main object of investigation: the performance of the economy at the end of a spending program.

4.2. Calibration. We calibrate the model with US data in line with the existing RBC literature on fiscal policy and government expenditure. Parameter values for tax rates, government share, capital share, depreciation rate, and time preference are taken from Strulik and Trimborn's (2012) recent calibration of the RBC model with US data. We set $\rho$ such that the real interest equals 6 percent per year (as in Barro et al., 1995) and we set $\beta$ such that households in equilibrium supply a quarter of their time on the labor market. At the pre-shock steady-state the government purchases 18 percent of output, i.e. $g \equiv G / y=0.18$. Altogether these values imply an investment rate of 20.5 percent. Table 1 summarizes the setup of parameters. 
TABle 1. Parameter Values

\begin{tabular}{cccccccccccccc}
\hline \hline$\tau_{a}$ & $\tau_{w}$ & $\tau_{c}$ & $\alpha$ & $A^{*}$ & $A_{0}$ & $\omega^{*}$ & $\omega_{0}$ & $\sigma$ & $\delta$ & $\rho$ & $g$ & $\gamma$ & $\ell^{*}$ \\
0.36 & 0.26 & 0.05 & 0.38 & 1 & 0.046 & 0 & 0.15 & 0.4 & 0.07 & 0.038 & 0.18 & 1.5 & 0.25 \\
\hline \hline
\end{tabular}

The quantitative results depend of course crucially on the assumed power of the government spending multiplier. Unfortunately the literature has not yet converged towards a generally accepted value for the multiplier. We try to meet the involved uncertainty by defining a reasonable benchmark case and by providing sensitivity analysis. For the benchmark case we set $\gamma=1.5$, which implies a long-run multiplier of 0.89 for a permanent increase of government purchases. This value lies in the middle of Barro's (1981) estimate of 0.62 and Baxter and King's (1993) estimate of 1.16. Since we embarked on this project, several studies provided new estimates of the multiplier. Barro and Redlick (2011) estimate a long-run multiplier between 0.5 and 0.6 (depending on the period of investigation) and Hall (2009) provided estimates between 0.13 and 0.56. Both studies infer the multiplier from military expenditures. Ramey (2011b) compiles a richer set of government spending variables and estimates a multiplier between 0.6 and 1.2 depending on estimation method and the time period investigated. Interestingly, Ramey does not find that the multiplier is larger when the interest rate is close to zero (as it was in 1939 - 1945 period). Ramey (2011a) surveys the earlier and recent quantitative literature on the government spending multiplier. Below we take the implied uncertainty about the "correct" size of spending multiplier into account by providing robustness checks of our results.

We define as "laissez-faire" the policy that keeps total purchases $G$ constant. This assumption is in contrast to the standard RBC modeling where laissez faire means that the government maintains a constant GDP share of purchases $g=G / y$. Holding $G$ constant instead, adds more realism to our model since it implies that the GDP share of government purchases rises after a negative shock of GDP already under laissez faire, i.e. without the additional expenditure triggered by the shock. We have checked that our results remain qualitatively unchanged if "laissez faire" is defined by a constant GDP share of government purchases.

For the computation of adjustment dynamics we apply the relaxation algorithm, which is in detail described in Trimborn et al. (2008). The method does not require linearization around the steadystate or any other transformation of the original dynamic system. It provides the exact solution (up to a user-specified error) irrespective of the deviation from steady-state and is thus a reliable tool for the investigation of big shocks, i.e. of an economy far away from its steady-state. 
In order to explore the dark side of fiscal stimulus we begin with a scenario in which a government spending shock is experienced at the steady-state and investigate the implied adjustment dynamics for investment, employment and output. We then consider how a temporary government expenditure program affects the speed of recovery from a recession. We substantiate the claim that the result of a negative multiplier in the medium run holds true irrespective of whether a fiscal expansion is put into effect in good times (at the steady-state) or in bad times when the economy has been hit by a recession. The numerical experiments allow for a quantitative assessment of the slowdown from recovery caused by "fiscal stimulus".

\section{Responses to Fiscal Stimulus Experienced at the Steady-State}

In this section we investigate the impulse responses when the economy is at the steady-state originally, as commonly assumed in quantitative business cycle experiments. Inspired by the VAR results we assume that our benchmark fiscal stimulus program lasts for 4 years. In our first experiment we relate directly to the phase diagram analysis by assuming that government expenditure increases by the same amount in any quarter for 4 years and then returns immediately to its steady-state level, i.e. the government shock is "rectangular". Specifically we consider an increase of $G$ by 2 percent of GDP per year. In our second experiment we re-investigate the hump shaped expenditure path extracted from Ramey (2011b) that we have used in the introduction.

Figure 3 shows impulse responses to the rectangular spending shock. Qualitatively, impulse responses confirm our results from phase diagram analysis. Fiscal stimulus very effectively raises employment and GDP at impact but it also drives private investment below steady-state level. This means that the aggregate capital stock is declining as long as fiscal stimulus is operative. At time of expiry of fiscal stimulus investment and capital stock reach their lowest level. In combination the responses of the inputs, capital and labor, imply that GDP falls below steady-state level in quarter 12 , i.e. about a year before stimulus expires. The output multiplier of spending is about 0.4 on impact and then declines continuously and turns negative in quarter 12.

We next consider the hump shaped spending shock extracted from Ramey (2011b) that we already explored in the introduction. The impulse responses predicted by the model are shown in Figure 4 . They can be confronted with the empirical impulse responses estimated by Ramey for a similar shock (The right hand side panels of Figure IV in Ramey, 2011b). GDP peaks at about the third quarter, declines afterwards and falls below steady-state level at about quarter 12. Investment is initially 
Figure 3: Impulse Responses: Rectangular Spending Shock
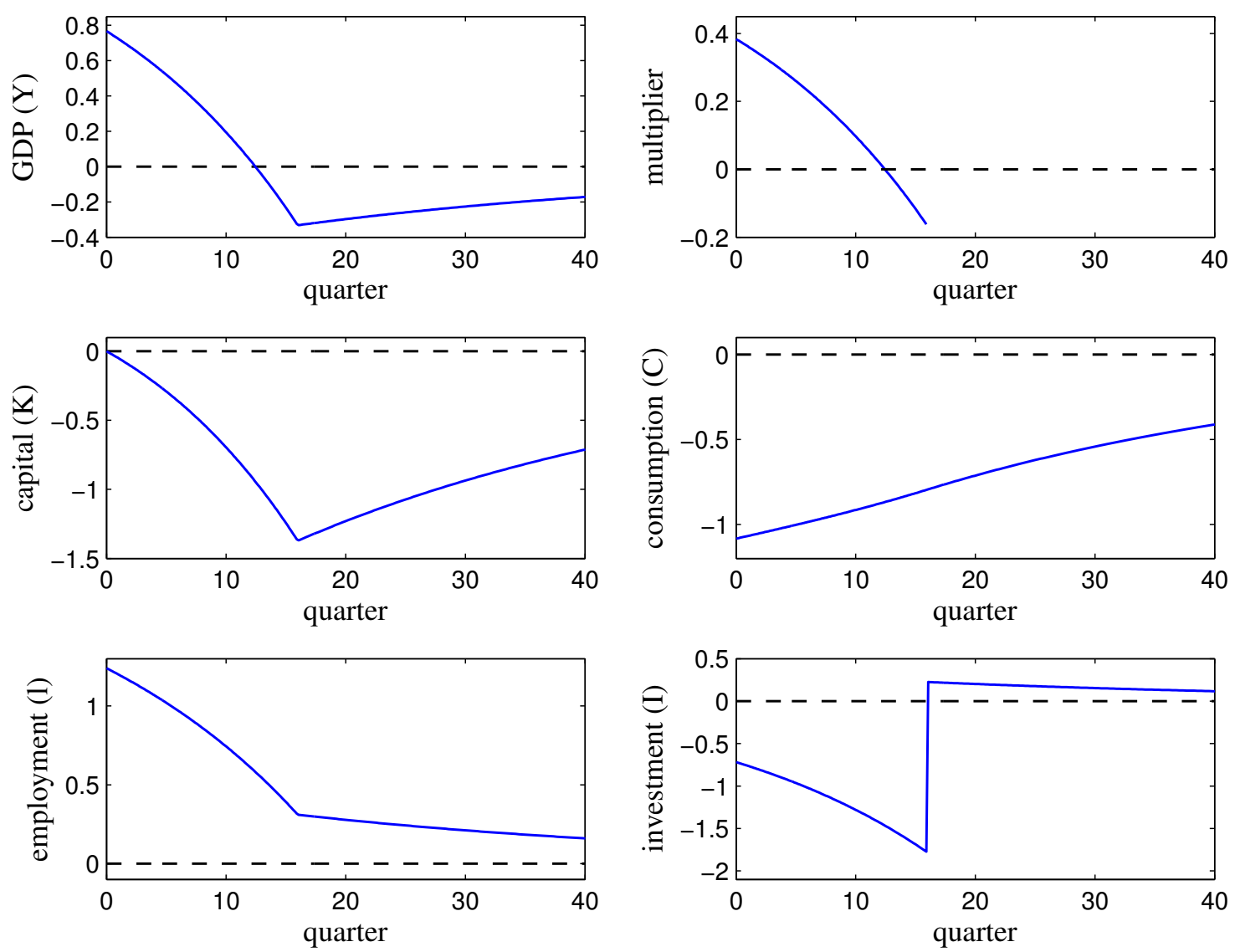

Impulse responses for a 4 year government spending shock of 2 percent of GDP annually. All variables are measured in terms of deviation from their steady-state. GDP and investment are measured in percentage units of steady-state GDP; capital, employment and consumption are measured in percentage units of their own steady-state level. The multiplier is measured as $\Delta Y(t) / \Delta G(t)$. See text for details.

shortly positive (due to the anticipation effect), falls below steady-state level in the third quarter and reaches a through at about the ninth quarter, after which it returns, mildly overshooting, towards steady-state level.

\section{RECOVERY From ReCESSiON}

Sometimes fiscal stimulus sets in when the economy is in a recession. If fiscal stimulus was caused by a war this might be purely incidentally but we could also imagine that being in a recession was actually the motivation for the fiscal stimulation of the economy. Based on the knowledge derived from steady-state analysis we then expect that stimulus is helpful to raise employment and GDP above laissez faire level on impact but slows down economic recovery in the medium run. At time of expiry of fiscal stimulus we expect GDP to be below laissez faire level. In the following we verify 
Figure 4: Impulse Responses: Hump Shaped Spending Shock
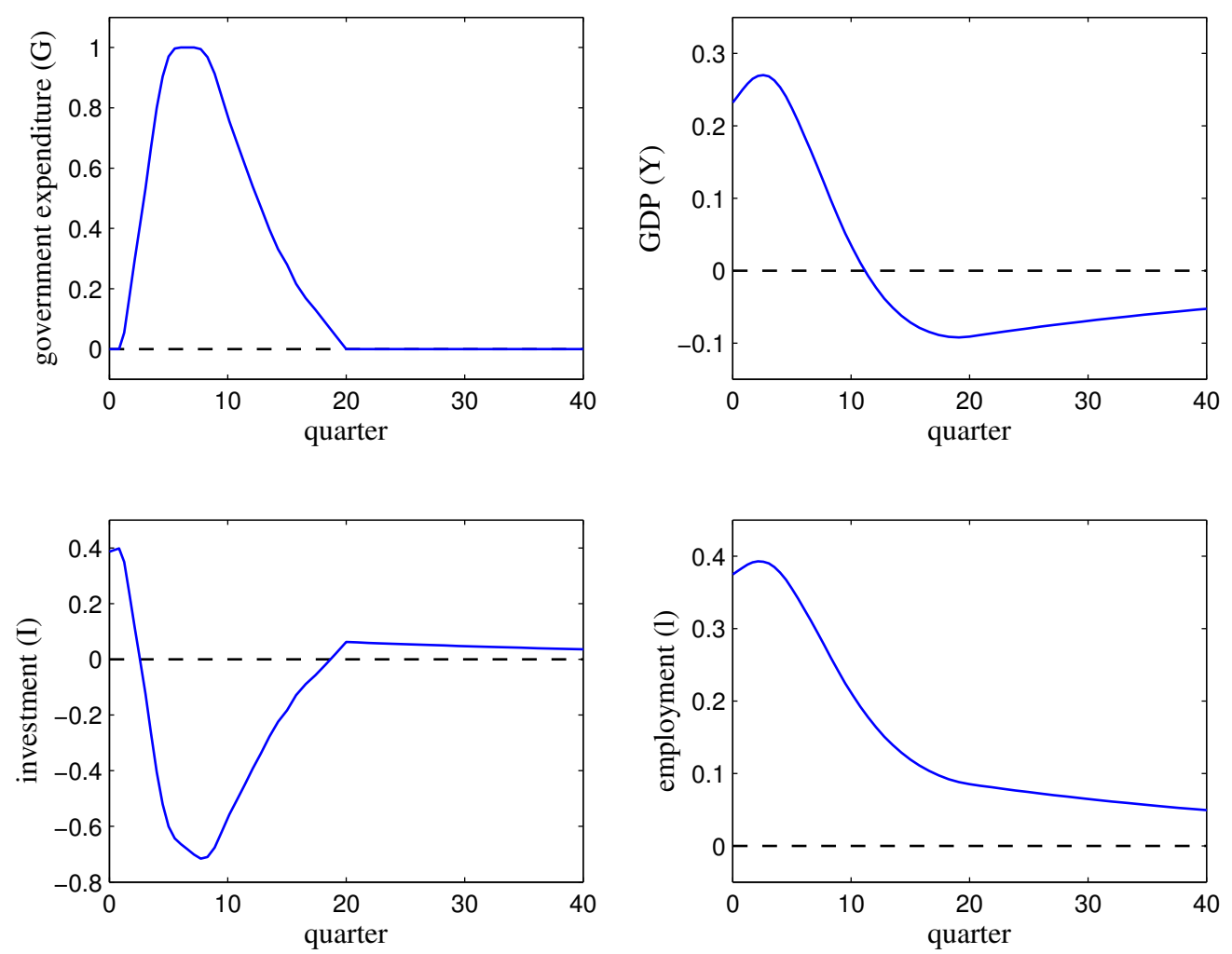

Impulse responses for the hump shaped spending shock extracted from Ramey (2011b), see Introduction. All variables are measured in terms of deviation from their steady-state. GDP, government expenditure, and investment are measured in percentage units of steady-state GDP; employment is measured in percentage units of steady-state employment.

this claim and investigate by how much fiscal stimulus slows down economic recovery in the medium run.

We model a recession by either an increasing efficiency wedge (the $A$-scenario) or an increasing labor wedge (the $\omega$-scenario). For the benchmark case we adjust either $A_{0}$, or $\omega_{0}$ such that an output gap of 7 percent below steady-state level results. The rate of recovery, $\sigma$, is assumed in both scenarios such that half of the original GDP gap is closed after two years by setting $\sigma=0.4$. We also provide sensitivity analysis with respect to the duration and scale of the spending program and with respect to the assumed size of output multiplier of government spending on impact. Throughout we focus on chronologically equally distributed, i.e. "rectangular" spending programs. In our benchmark scenario we assume that the government reacts to the recession with a deficit-financed fiscal stimulus of $\Delta G$ such that $\Delta g=0.02$ for 4 years.

The economy is predicted to recover quite differently under the $A$-scenario and the $\omega$-scenario. In particular, the initial slump of factor inputs is much harder under the $\omega$-scenario. This result is 
not surprising. It follows naturally from the fact that, if productivity $A$ stays constant, the initial drop of output $A k^{\alpha} \ell^{1-\alpha}$ has to be explained solely by the drop of labor input $\ell$. Consequently, the government expenditure program is less successful in rising employment under the $\omega$-scenario. ${ }^{7}$ But notwithstanding these large differences, fiscal stimulus is predicted to crowd out about the same investment under both scenarios. This fact explains why there is actually little difference discernable across the two types of recessions once we focus on the deviation of GDP from its level under laissez faire recovery.

Figure 5 shows the deviation of GDP from its steady-state level under laissez faire recovery for the two recessions and alternative duration of the spending program. For the benchmark case, reflected by solid lines, fiscal stimulus expires after 4 years. On impact, deficit spending raises output by about 0.9 percent above laissez-faire level with subsequently decreasing lead. During an initial period, immediately after deficit spending becomes operative, the positive effect on GDP through employment dominates. The negative effect through falling investment is not yet effective because capital stock is a state variable, i.e. it cannot jump and adjusts slowly over time.

After some time, however, the effect of dampened and delayed investment becomes dominating. After about 3 years, at a time when the economy has closed about 60 percent of the initial gap, and when deficit spending is still running for one more year, the negative investment effect becomes dominating and GDP falls below its laissez-faire level. The greatest distance from laissez-faire recovery is reached at the time when deficit spending is terminated, after which the "stimulated" economy converges towards the laissez-faire path from below, catching up the loss as time goes to infinity.

We next assume that the same total increase of government outlays is stretched over an alternative number of years. A longer spread of the stimulus thus reduces the expenditure per year. To be specific, we assume that the total outlays of our benchmark case are either spent over 2 years, implying $\Delta g=0.04$ annually, or over 6 years, implying $\Delta g=0.013$. Dashed lines show the implied deviation from laissez faire when total outlays are spent over 2 years and dotted lines show results for the 6-year spending program. If deficit spending is performed over a shorter period of time, the triggered initial increase of GDP is stronger and of shorter duration, and the fall below laissez-faire

\footnotetext{
7 In an earlier version of this paper we investigated in detail the impulse responses of various macro-economic aggregates for an $A$-recession and for an $\omega$-recession with and without fiscal stimulus (Strulik and Trimborn, 2011). There we investigated also alternative assumptions about the severity of the recession and its persistence and showed that these features have little impact on results once we focussed on the predicted deviation of stimulated GDP from laissez faire recovery.
} 
Figure 5: Recovery from Recession and the Timing of Deficit Spending
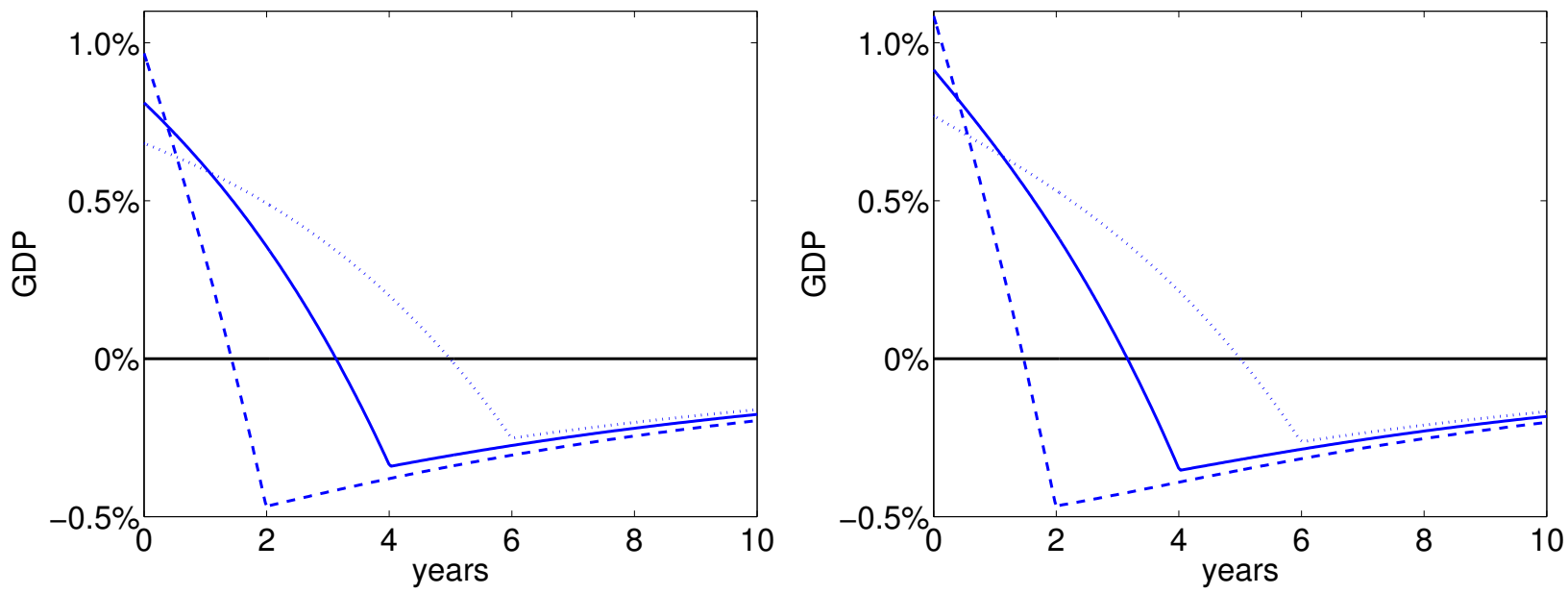

Recovery from an output drop of 7 percent below steady-state level caused by an efficiency wedge (left) and labor wedge (right). The figures shows deviation of GDP from its level under laissez faire recovery. Solid lines: benchmark case (4 years deficit spending). dashed lines: 2 years deficit spending, dotted lines: 6 years deficit spending.

is harder. The opposite is true for a prolonged spending program. Regardless of the duration of the stimulus, the deviation from laissez faire after expiry of fiscal stimulus follows almost the same path. The result reflects the fact that the induced loss of permanent income depends mainly on total government purchases, which have been assumed to be the same in all three cases.

Apparently, each of these spending schedules causes GDP to fall below steady state at some point of time. If expenditures are concentrated on the first periods, GDP declines very fast, falls below steady state soon and goes through a deep and long-lasting slack period. If the expenditure plan is more persistent (but starts at a lower level), output gains are more sustainable and output falls below steady state at a later point of time.

We next investigate the deviation from laissez-faire recovery for alternative assumptions about the power of the output multiplier. Since all multipliers are decaying over time and turn negative eventually, we measure the power of a multiplier by the change in output that would be provoked if the increase of government expenditure were permanent. As a rule, a high multiplier for permanent expenditure is associated with a high impact multiplier for temporary expenditure.

In Figure 6 solid lines reiterate the benchmark case. Dashed lines reflect the outcome when $\gamma=5$. In this case the implied Frisch elasticity is $3 / 5$, closer to the micro estimates (e.g. Pencavel, 1986). The weaker response of employment implies a reduction of the long-run multiplier from 0.89 to 0.54. The impact multiplier of the temporary program declines from 0.43 to 0.21 . Dotted lines 
Figure 6: Robustness W.R.T. Magnitude of the Government Multiplier
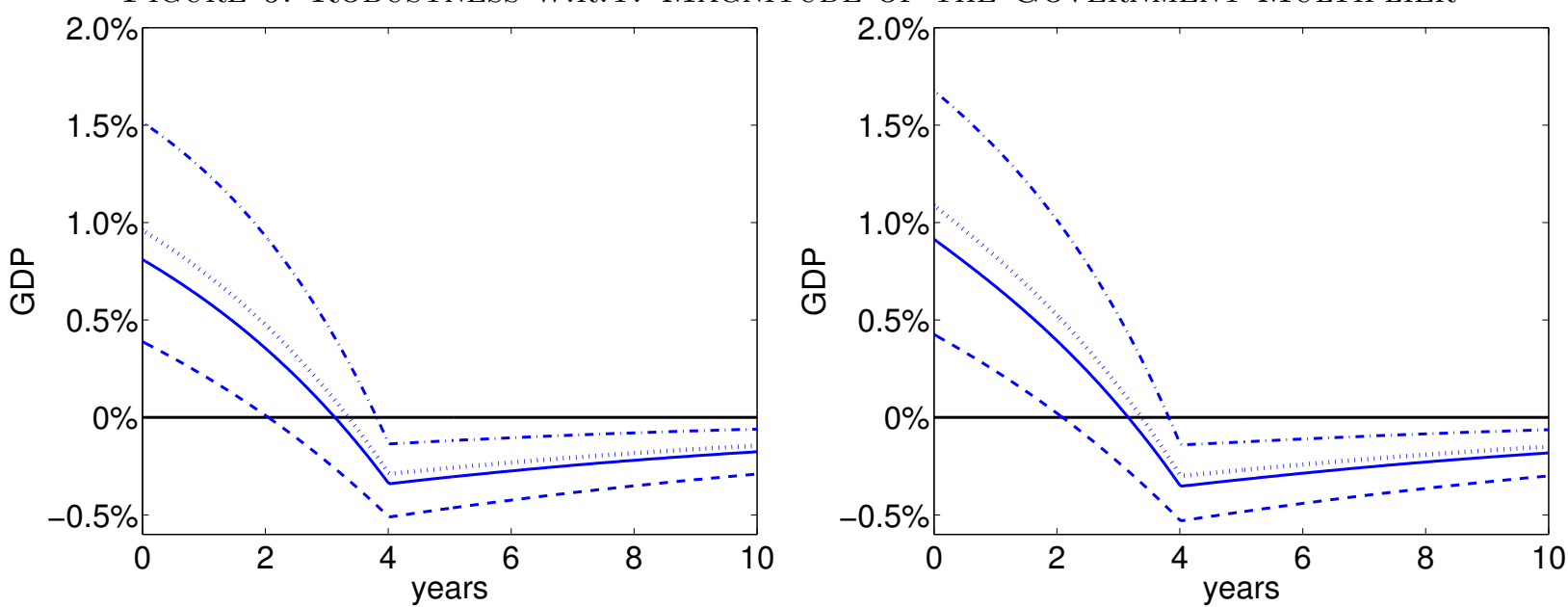

Recovery from an output drop of 7 percent below steady-state level caused by an efficiency wedge (left) and labor wedge (right). Solid lines: benchmark case, dashed lines: $\gamma=5$, dotted lines: $\gamma=1$, dashed-dotted lines $\gamma=0$.

show the result for the case of $\gamma=1$, which is frequently investigated in the $\mathrm{RBC}$ literature. Then, the implied Frisch elasticity of labor supply assumes a value of 3 and the long-run multiplier of government spending is 0.97 (impact multiplier 0.50). Finally, dashed-dotted lines reflect the case of $\gamma=0$, i.e. the case when labor enters linearly in utility. This assumption gets theoretical foundation from the indivisible labor approach and has been very popular in the RBC literature as well. In this case the long-run multiplier is 1.22 and the impact multiplier of the spending temporary program is 0.73 .

Naturally, our main finding that GDP falls below its level under laissez-faire recovery before deficit spending ends (at year 4) is obtained regardless of the assumed power of the multiplier. The model produces more optimistic predictions for the short run when the multiplier is more powerful. In this case the positive effect through higher employment is stronger such that the initial impact is larger and the fall below laissez faire is smaller. The negative effect through delayed investment, however, is never overturned. On the other hand, if the implied labor supply elasticity is closer to what micro-econometricians suggest and the long-run multiplier is smaller than assumed by our benchmark scenario, the fall of GDP below laissez-faire level happens earlier and is harder.

Finally we consider alternative scales of the deficit spending. In conjunction with the surprisingly small impact of the ARRA fiscal stimulus on recovery from recession, it has been argued that the spending program was "too small". We know already from the theoretical part of the paper that our main result is independent from size. A quantitative investigation is nevertheless interesting 
Figure 7: Robustness W.R.T. Scale of Deficit Spending
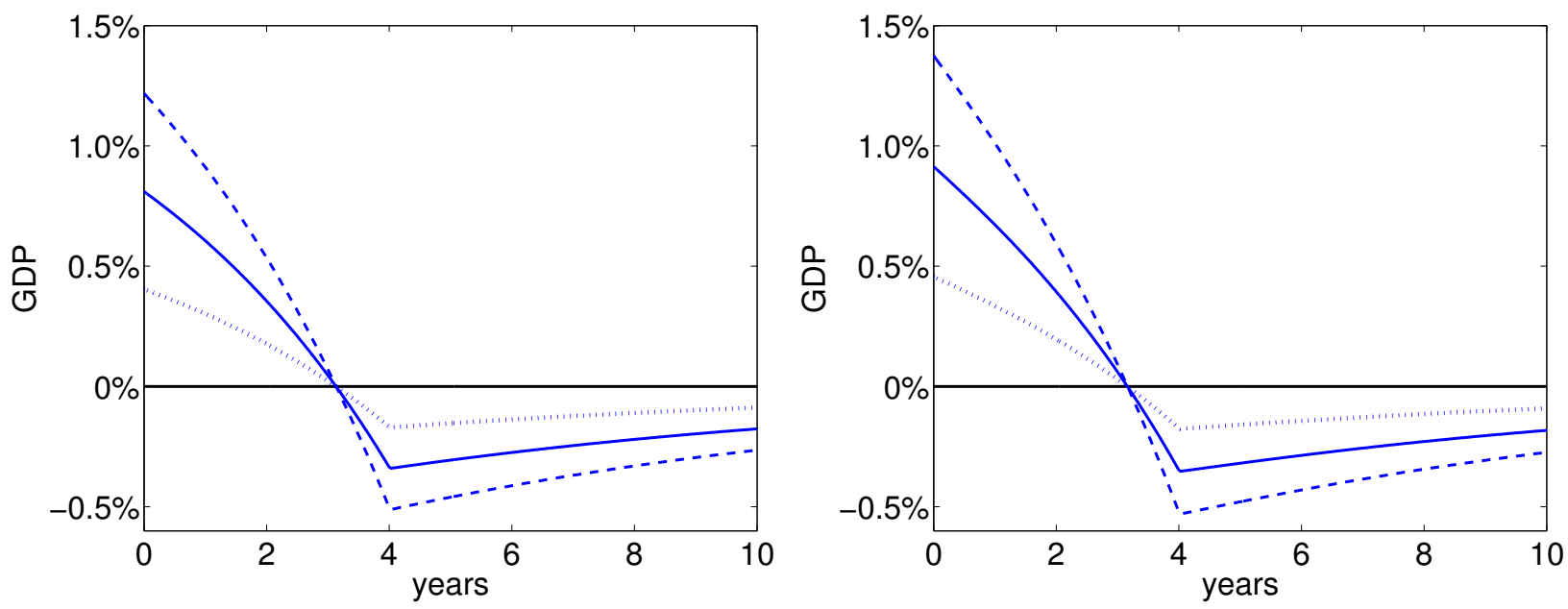

Recovery from an output drop of 7 percent below steady-state level caused by an efficiency wedge (left) and labor wedge (right). Solid lines: benchmark case, dashed lines: $\Delta g=0.01$, dotted lines: $\Delta g=0.03$.

since it reveals a trade-off: A large deficit spending program leads to a large improvement of GDP on impact and a large relapse of GDP below the laissez-faire recovery level at time of expiry.

The trade-off is demonstrated in Figure 7 where solid lines reiterate adjustment dynamics of the benchmark model. Dashed lines show adjustment dynamics when the increase of government purchases is much higher than assumed for our benchmark scenario ( $\Delta G$ rises such that the GDP share $\Delta g$ increases by 3 percentage points). The dotted line shows adjustment dynamics when the increase of government purchases is smaller than in our benchmark scenario ( $\Delta g$ increases by one percentage point). As a rule, economic recovery in the medium run is slower when the scale of the deficit spending program is larger.

\section{Final Remarks}

In this paper we have investigated the phenomenon that output falls below its steady-state level before a deficit spending program expires. This phenomenon is observed from VAR analysis and predicted by neoclassical and new-Keynesian business cycle models alike. Although the undershooting of output appears as a general phenomenon it has so far never attracted the attention of economic research and thus it has not yet been explained by economic theory. In order to explain this dark side of fiscal stimulus we set up a simple business cycle model and have formally shown that the aggregate capital stock has to be below laissez faire level before a deficit spending program expires. This explains why output falls short of its steady-state level as well. If deficit spending sets off in a 
recession this means that it slows down recovery in the medium run. Before deficit spending expires, GDP falls short of its level under laissez-faire recovery.

It is perhaps appropriate to emphasize that we have never employed a welfare argument and thus have not argued against deficit spending as such. Temporarily increasing government spending could be very sensible in order to reduce individual hardships after a severe shock and may even raise aggregate welfare. We have just tried to explain why fiscal stimulus has a dark side. The price of a boost of GDP and employment on impact is paid later on, when recovery turns out to be slower than under laissez-faire. This price is not paid in a very distant future (by the next generation) but relatively soon, before deficit spending expires. 


\section{APPENDIX}

Derivation of the $\dot{c}=0$ isocline. From $\dot{c}=0$ the capital-labor ratio is given by

$$
\frac{k}{\ell}=\left(\frac{A \alpha}{\delta+\rho}\right)^{\frac{1}{1-\alpha}}
$$

We differentiate the households' first order condition

$$
c=\frac{(1-\ell)^{\gamma} w}{\beta}=\frac{1-\alpha}{\beta} A(1-\ell)^{\gamma}\left(\frac{k}{\ell}\right)^{\alpha}
$$

keeping $k / \ell$ constant and obtain

$$
\left.\frac{d c}{d \ell}\right|_{\dot{c}=0}=-\frac{\gamma c}{1-\ell}<0
$$

We thus calculate the slope of $\dot{c}=0$ as

$$
\frac{d c}{d k}=-\left(\frac{A \alpha}{\delta+\rho}\right)^{-\frac{1}{1-\alpha}} \frac{\gamma c}{1-\ell}<0
$$

For $\gamma \rightarrow \infty$ the $\dot{c}=0$ line is vertical in the $(k, c)$-space, and for $\gamma=0$ it is horizontal. For any other value it is downward sloping. Note that the $\dot{c}=0$ isocline does not shift if government spending $G$ increases. Consumption is rising for a capital labor ratio above steady-state level, implying that the arrows of motion point upward to the right of the isocline. Consumption is falling for a capital labor ratio below steady-state level, arrows point downward to the left of the isocline.

Derivation of the $\dot{k}=0$ isocline. From $\dot{k}=0$ we get

$$
c=A k^{\alpha} \ell^{1-\alpha}-\delta k-G
$$

Together with equation (17) this provides (19)

$$
\frac{1-\alpha}{\beta} A(1-\ell)^{\gamma}\left(\frac{k}{\ell}\right)^{\alpha}=A k^{\alpha} \ell^{1-\alpha}-\delta k-G
$$

From (19) we calculate the differential $d \ell / d k$ :

$$
\left.\frac{d \ell}{d k}\right|_{\dot{k=0}}=-\frac{\alpha A k^{\alpha-1} \ell^{1-\alpha}-\delta-\frac{\alpha c}{k}}{A(1-\alpha) k^{\alpha} \ell^{-\alpha}+\frac{\gamma c}{1-\ell}+\frac{\alpha c}{\ell k}}=-\frac{r-\frac{\alpha c}{k}}{w+\frac{\gamma c}{1-\ell}+\frac{\alpha c}{\ell k}} .
$$


In combination with equation (18) we calculate the slope of the $\dot{k}=0$ isocline as

$$
\frac{d c}{d k}=A \alpha k^{\alpha-1} \ell^{1-\alpha}-\delta-A k^{\alpha}(1-\alpha) \ell^{-\alpha} \frac{r-\frac{\alpha c}{k}}{w+\frac{\gamma c}{1-\ell}+\frac{\alpha c}{\ell k}}=r+w \frac{\frac{\alpha c}{k}-r}{w+\frac{\gamma c}{1-\ell}+\frac{\alpha c}{\ell k}} .
$$

In case of inelastic labor supply the last term on the right hand side vanishes and $d c / d k=r=$ $\partial Y / \partial K-\delta$. In this case the slope would be positive and diminishing for low $k$. Once the capital stock is larger than the golden rule capital stock, the slope would turn negative. The $\dot{c}=0$ and $\dot{k}=0$ isoclines intersects at a capital stock smaller than the golden rule capital stock where the slope of $\dot{k}=0$ is positive.

Elastic labor supply changes the slope of the $\dot{k}=0$ isocline. Since the economy produces with a Cobb-Douglas technology it is straightforward to calculate capital and labor income shares as $\alpha y$ and $(1-\alpha) y$. We take $(r+\delta) k=\alpha y$ and insert the steady state condition $y=c+\delta k+G$ and get

$$
(r+\delta) k=\alpha(c+\delta k+G) \quad \Leftrightarrow \quad r k=\alpha c-(1-\alpha) \delta k+\alpha G \quad \Leftrightarrow \quad r=\alpha \frac{c}{k}-(1-\alpha) \delta+\alpha \frac{G}{k} .
$$

With this expression the slope modifies to

$$
\frac{d c}{d k}=r+w \frac{(1-\alpha) \delta-\alpha \frac{G}{k}}{w+\frac{\gamma c}{1-\ell}+\frac{\alpha c}{\ell k}}
$$

Hence, for $G=0$ the slope of the isocline is steeper than for the case of inelastic labor supply. If $G$ is sufficiently small, the intersection point of $\dot{c}=0$ and $\dot{k}=0$ is where $d c / d k>0$. Capital is falling for values of consumption above the isocline (implying that arrows point to the left in this region), and rising for values of consumption below the curve (arrows point to the right).

Finally, we calculate how government spending shifts the $\dot{k}=0$ isocline. Holding capital constant we get from $\dot{k}=0$

$$
\frac{d c}{d G}=-1+A(1-\alpha) k^{\alpha} \ell^{-\alpha} \frac{d \ell}{d G}=-1+w \frac{d \ell}{d G}
$$

If households would not adjust labor supply, one dollar extra government spending implies one dollar less of consumption for given capital stock. From equation (19) we get for constant $k$

$$
\left.\frac{d \ell}{d G}\right|_{\dot{k}=0}=\frac{1}{w+\frac{\gamma c}{1-\ell}+\frac{\alpha c}{\ell k}} .
$$


Together this implies

$$
\frac{d c}{d G}=-1+\frac{w}{w+\frac{\gamma c}{1-\ell}+\frac{\alpha c}{\ell k}}<0
$$

Hence, the $\dot{k}=0$ isocline shifts down when government spending increases. 


\section{References}

Aiyagari, S.R., L.J. Christiano, and M. Eichenbaum, 1992, The output, employment, and interest rate effects of government consumption, Journal of Monetary Economics 30, 73-86.

Angeletos, G.-M. and V. Panousi, 2009, Revisiting the supply side effects of government spending, Journal of Monetary Economics 56, 137-153.

Barro, R,J., 1981, Output effects of government purchases, Journal of Political Economy 89, 10861121.

Barro, R., G. Mankiw and X. Sala-i-Martin, 1995. Capital mobility in neoclassical models of growth. American Economic Review 85, 103-115

Barro, R,J., and C.J. Redlick, 2011, Macroeconomic effects from government purchases and taxes, Quarterly Journal of Economics 126, 51-102.

Barro, R.J. and X. Sala-i-Martin, 2004, Economic Growth, MIT Press, Cambridge, MA.

Baxter, M. and R.G. King, 1993, Fiscal policy in general equilibrium, American Economic Review 83, 315-334.

Blanchard, O, and R. Perotti, 2002, An empirical characterization of the dynamic effects of changes in government spending and taxes on output, Quarterly Journal of Economics 1329-1368.

Christiano, L.J. and M. Eichenbaum, and S. Rebelo, 2011, When is the government spending multiplier large? Journal of Political Economy 119, 78-121.

Chari, V.V., P.J. Kehoe, and E.R. McGrattan, 2002, Accounting for the Great Depression, American Economic Review 92, 22-27.

Chari, V.V., P.J. Kehoe, and E.R. McGrattan, 2007, Business cycle accounting, Econometrica 75, 781-836.

Cogan, J.F., T. Cwik, J.B. Taylor, V. Wieland, 2010, New Keynesian versus old Keynesian government spending multipliers, Journal of Economic Dynamics and Control 34, 281-295.

Cole, H.L. and L.E. Ohanian, 2002, The U.S. and U.K. Great Depressions through the lens of neoclassical growth theory, American Economic Review 92, 28-32.

Cole, H.L. and L.E. Ohanian, 2004, New deal policies and the persistence of the Great Depression: a general equilibrium analysis, Journal of Political Economy 112, 779-816.

Hall, R.E., 2009, By how much does GDP rise if the government buys more output? Brookings Papers on Economic Activity Fall 2009, 183-228.

Hansen, G., 1985, Indivisible labor and the business cycle, Journal of Monetary Economics 16, 309-327.

Kehoe, T.J. and E.C. Prescott, 2002, Great Depressions of the 20th century, Review of Economic Dynamics 5, 1-18. 
Kehoe, T.J. and E.C. Prescott, 2007, Great Depressions of the Twentieth Century, Federal Reserve Bank of Minneapolis.

King, R.G., C. Plosser, and S. Rebelo, 1988, Production, growth, and business cycles: I. The basic neoclassical model, Journal of Monetary Economics 21, 195-232.

King, R.G., and S. Rebelo, 1999, Resuscitating real business cycles, in: B. Taylor and M. Woodford (eds.), Handbook of Macroeconomics 1B, 927-1007.

Ludvigson, S., 1996, The macroeconomic effects of government debt in a stochastic growth model, Journal of Monetary Economics 38, 25-45.

Ohanian, L.E., 2010, The economic crisis from a neoclassical perspective, Journal of Economic Perspectives 24(4), 45-66.

Pencavel, J., 1986, Labor supply of men: a survey, in: O. Ashenfelter and R. Layard, eds., Handbook of Labor Economics, North-Holland, Amsterdam, 3-102.

Ramey, V.A., 2011a, Can government purchases stimulate the economy?, Journal of Economic Literature 49, 673-685.

Ramey, V.A., 2011b, Identifying government spending shocks: it's all in the timing, Quarterly Journal of Economics 126, 1-50.

Rogerson, R., 1988, Indivisible labor, lotteries and equilibrium, Journal of Monetary Economics 21, $3-16$.

Smets, F. and R. Wouters, 2007, Shocks and frictions in US business cycles: a Bayesian DSGE approach, American Economic Review 97, 586-606.

Strulik, H. and T. Trimborn, 2009, Fiscal Stimulus: A Neoclassical Perspective, University of Hannover, Working Paper 421.

Strulik, H. and T. Trimborn, 2010, Anticipated tax reforms and temporary tax cuts: a general equilibrium analysis, Journal of Economic Dynamics and Control 34, 2141-2158.

Strulik, H. and T. Trimborn, 2011, The dark side of fiscal stimulus, University of Hannover, Working Paper 466.

Strulik, H. and T. Trimborn, 2012, Laffer strikes again: dynamic scoring of capital taxes, European Economic Review 56, 1180-1199.

Strulik, H. and T. Trimborn, 2013, The Janus-faced role of variable capital utilization in growth and business cycle theory, Discussion paper, University of Goettingen.

Trimborn, T., K.-J. Koch, and T.M. Steger, 2008, Multi-dimensional transitional dynamics: A simple numerical procedure, Macroeconomic Dynamics, 12, 1-19.

Wieland, V., T. Cwik, G.J. Mueller, S. Schmidt, and M. Wolters 2012, A new comparative approach to macroeconomic modeling and policy analysis, Journal of Economic Behavior $\mathcal{G}$ Organization $83,523-541$. 


\section{Bisher erschienene Diskussionspapiere}

Nr. 150: Strulik, Holger; Trimborn, Timo: The Dark Side of Fiscal Stimulus, Januar 2013

Nr. 149: Prettner, Klaus: Public education, technological change and economic prosperity, Januar 2013

Nr. 148: Lankau, Matthias; Bicskei, Marianna; Bizer, Kilian: Cooperation Preferences in the Provision of Public Goods: An Experimental Study on the Effects of Social Identity, Dezember 2012

Nr. 147: Krenz, Astrid: Modeling Services Sectors' Agglomeration within a New Economic Geography Model, Dezember 2012

Nr. 146: Krenz, Astrid: A Panel Co-integration Analysis of Industrial and Services Sectors' Agglomeration in the European Union, Dezember 2012

Nr. 145: Strulik, Holger: Knowledge and Growth in the Very Long Run, November 2012

Nr. 144: Baskaran, Thushyanthan: Ideology and fiscal policy: quasi-experimental evidence from the German States, Oktober 2012

Nr. 143: Ehlers, Tim; Schwager, Robert: Honest Grading, Grade Inflation and Reputation, Oktober 2012

Nr. 142: Gehringer, Agnieszka: Another look at the determinants of current account imbalances in the European Union: An empirical assessment, Oktober 2012

Nr. 141: Strulik, Holger; Werner, Katharina: Life Expectancy, Labor Supply, and Long-Run Growth: Reconciling Theory and Evidence, September 2012

Nr. 140: Strulik, Holger; Prettner, Klaus; Prskawetz, Alexia: The Past and Future of Knowledgebased Growth, September 2012

Nr. 139: Prettner, Klaus; Trimborn, Timo: Demographic change and R\&D-based economic growth: reconciling theory and evidence, September 2012

Nr. 138: König, Jörg; Ohr, Renate: Homogeneous groups within a heterogeneous community Evidence from an index measuring European economic integration, August 2012

Nr. 137: Schwager, Robert: Student Loans in a Tiebout Model of Higher Education, Juli 2012

Nr. 136: Martínez-Zarzoso, Inmaculada: Exporting and Productivity: Evidence for Egypt and Morocco, April 2012

Nr. 135: König, Jörg; Ohr, Renate: Messung ökonomischer Integration in der Europäischen Union Entwicklung eines EU-Integrationsindexes -, April 2012

Nr. 134: Gehringer, Agnieszka: Financial liberalization, growth, productivity and capital accumulation: The case of European integration, März 2012

Nr. 133: Berner, Eike; Birg, Laura: Retailers and Consumers. The pass-through of import price changes, März 2012

Nr. 132: Gehringer, Angnieszka: Current accounts in Europe: implications of the external imbalances for the future of the common monetary policy, März 2012

Nr. 131: Ohr, Renate; Özalbayrak, Mehmet: The Euro - A „MUST“ for Small European States?, Januar 2012

Nr. 130: Zeddies, Götz: Der Euro als Triebfeder des deutschen Exports?, November 2011

Nr. 129: Geishecker, Ingo; Siedler, Thomas: Job Loss Fears and (Extreme) Party Identification: First Evidence from Panel Data, Oktober 2011

Nr. 128: König, Jörg; Ohr, Renate: Small but Beautiful? Economic Impacts of the Size of Nations in the European Union, August 2011 
Nr. 127: Schüder, Stefan: Monetary Policy Trade-Offs in a Portfolio Model with Endogenous Asset Supply, Juni 2011

Nr. 126: Hiller, Sanne: The Export Promoting Effect of Emigration: Evidence from Denmark, Juni 2011

Nr. 125: Martínez-Zarzoso, Inmaculada; Voicu, Anca M.; Vidovic, Martina: CEECs Integration into Regional and Global Production Networks, Mai 2011

Nr. 124: Roth, Felix; Gros, Daniel; Nowak-Lehmann D., Felicitas: Has the Financial Crisis eroded Citizens' Trust in the European Central Bank? Panel Data Evidence for the Euro Area, 1999-2011, Mai 2011, Revised Version März 2012

Nr. 123 Dreher, Axel; Vreeland, James Raymond : Buying Votes and International Organizations, Mai 2011

Nr. 122: Schürenberg-Frosch, Hannah: One Model fits all? Determinants of Transport Costs across Sectors and Country Groups, April 2011

Nr. 121: Verheyen, Florian: Bilateral Exports from Euro Zone Countries to the US - Does Exchange Rate Variability Play a Role?, April 2011

Nr. 120: Ehlers, Tim: University Graduation Dependent on Family's Wealth, Ability and Social Status, April 2011

Nr. 119: Cho, Seo-Young; Dreher, Axel; Neumayer, Eric: The Spread of Anti-trafficking Policies Evidence from a New Index, März 2011

Nr. 118: Cho, Seo-Young; Vadlamannati, Krishna Chaitanya: Compliance for Big Brothers: An Empirical Analysis on the Impact of the Anti-trafficking Protocol, Februar 2011

Nr. 117: Nunnenkamp, Peter; Öhler, Hannes: Donations to US based NGOs in International Development Cooperation: How (Un-)Informed Are Private Donors?, Februar 2011

Nr. 116: Geishecker, Ingo; Riedl, Maximilian: Ordered Response Models and Non-Random Personality Traits: Monte Carlo Simulations and a Practical Guide, Revised Version Februar 2012

Nr. 115: Dreher, Axel; Gassebner, Martin; Siemers, Lars-H. R.: Globalization, Economic Freedom and Human Rights, Oktober 2010

Nr. 114: Dreher, Axel; Mikosch, Heiner; Voigt, Stefan: Membership has its Privileges - The Effect of Membership in International Organizations on FDI, Oktober 2010

Nr. 113: Fuchs, Andreas; Klann, Nils-Hendrik: Paying a Visit: The Dalai Lama Effect on International Trade, Oktober 2010

Nr. 112: Freitag, Stephan: Choosing an Anchor Currency for the Pacific, Oktober 2010

Nr. 111: Nunnenkamp, Peter; Öhler, Hannes: Throwing Foreign Aid at HIV/AIDS in Developing Countries: Missing the Target?, August 2010

Nr. 110: Ohr, Renate; Zeddies, Götz: „Geschäftsmodell Deutschland“ und außenwirtschaftliche Ungleichgewichte in der EU, Juli 2010

Nr. 109: Nunnenkamp, Peter; Öhler, Hannes: Funding, Competition and the Efficiency of NGOs: An Empirical Analysis of Non-charitable Expenditure of US NGOs Engaged in Foreign Aid, Juli 2010

Nr. 108: Krenz, Astrid: La Distinction reloaded: Returns to Education, Family Background, Cultural and Social Capital in Germany, Juli 2010

Nr. 107: Krenz, Astrid: Services sectors' agglomeration and its interdependence with industrial agglomeration in the European Union, Juli 2010

Nr. 106: Krenz, Astrid; Rübel, Gerhard: Industrial Localization and Countries' Specialization in the European Union: An Empirical Investigation, Juli 2010 
Nr. 105: Schinke, Jan Christian: Follow the Sun! How investments in solar power plants in Sicily can generate high returns of investments and help to prevent global warming, Juni 2010

Nr. 104: Dreher, Axel; Sturm, Jan-Egbert; Vreeland, James Raymon: Does membership on the Security Council influence IMF conditionality?, Juni 2010

Nr. 103: Öhler, Hannes; Nunnenkamp, Peter; Dreher, Axel: Does Conditionality Work? A Test for an Innovative US Aid Scheme, Juni 2010

Nr. 102: Gehringer, Agnieszka: Pecuniary Knowledge Externalities in a New Taxonomy: Knowledge Interactions in a Vertically Integrated System, Juni 2010

Nr. 101: Gehringer, Agnieszka: Pecuniary Knowledge Externalities across European Countries - are there leading Sectors?, Juni 2010

Nr. 100: Gehringer, Agnieszka: Pecuniary Knowledge Externalities and Innovation: Intersectoral Linkages and their Effects beyond Technological Spillovers, Juni 2010

Nr. 99: Dreher, Axel; Nunnenkamp, Peter; Öhler, Hannes: Why it pays for aid recipients to take note of the Millennium Challenge Corporation: Other donors do!, April 2010

Nr. 98: Baumgarten, Daniel; Geishecker, Ingo; Görg, Holger: Offshoring, tasks, and the skill-wage pattern, März 2010

Nr. 97: Dreher, Axel; Klasen, Stephan; Raymond, James; Werker, Eric: The costs of favoritism: Is politically-driven aid less effective?, März 2010

Nr. 96: Dreher, Axel; Nunnenkamp, Peter; Thiele, Rainer: Are 'New' Donors Different? Comparing the Allocation of Bilateral Aid between Non-DAC and DAC Donor Countries, März 2010

Nr. 95: Lurweg, Maren; Westermeier, Andreas: Jobs Gained and Lost through Trade - The Case of Germany, März 2010

Nr. 94: Bernauer, Thomas; Kalbhenn, Anna; Koubi, Vally; Ruoff, Gabi: On Commitment Levels and Compliance Mechanisms - Determinants of Participation in Global Environmental Agreements, Januar 2010

Nr. 93: Cho, Seo-Young: International Human Rights Treaty to Change Social Patterns - The Convention on the Elimination of All Forms of Discrimination against Women, Januar 2010

Nr. 92: Dreher, Axel; Nunnenkamp, Peter; Thiel, Susann; Thiele, Rainer: Aid Allocation by German NGOs: Does the Degree of Public Refinancing Matter?, Januar 2010

Nr. 91: Bjørnskov, Christian; Dreher, Axel; Fischer, Justina A. V.; Schnellenbach, Jan: On the relation between income inequality and happiness: Do fairness perceptions matter?, Dezember 2009

Nr. 90: Geishecker, Ingo: Perceived Job Insecurity and Well-Being Revisited: Towards Conceptual Clarity, Dezember 2009

Nr. 89: Kühl, Michael: Excess Comovements between the Euro/US dollar and British pound/US dollar exchange rates, November 2009

Nr. 88: Mourmouras, Alex, Russel, Steven H.: Financial Crises, Capital Liquidation and the Demand for International Reserves, November 2009

Nr. 87: Goerke, Laszlo, Pannenberg, Markus: An Analysis of Dismissal Legislation: Determinants of Severance Pay in West Germany, November 2009

Nr. 86: Marchesi, Silvia, Sabani, Laura, Dreher, Axel: Read my lips: the role of information transmission in multilateral reform design, Juni 2009

Nr. 85: Heinig, Hans Michael: Sind Referenden eine Antwort auf das Demokratiedilemma der EU?, Juni 2009

Nr. 84: El-Shagi, Makram: The Impact of Fixed Exchange Rates on Fiscal Discipline, Juni 2009

Nr. 83: Schneider, Friedrich: Is a Federal European Constitution for an Enlarged European Union Necessary? Some Preliminary Suggestions using Public Choice Analysis, Mai 2009 
Nr. 82: Vaubel, Roland: Nie sollst Du mich befragen? Weshalb Referenden in bestimmten Politikbereichen - auch in der Europapolitik - möglich sein sollten, Mai 2009

Nr. 81: Williamson, Jeffrey G.: History without Evidence: Latin American Inequality since 1491, Mai 2009

Nr. 80: Erdogan, Burcu: How does the European Integration affect the European Stock Markets?, April 2009

Nr. 79: Oelgemöller, Jens; Westermeier, Andreas: RCAs within Western Europe, März 2009

Nr. 78: Blonski, Matthias; Lilienfeld-Toal, Ulf von: Excess Returns and the Distinguished Player Paradox, Oktober 2008

Nr. 77: Lechner, Susanne; Ohr, Renate: The Right of Withdrawal in the Treaty of Lisbon: A game theoretic reflection on different decision processes in the EU, Oktober 2008

Nr. 76: Kühl, Michael: Strong comovements of exchange rates: Theoretical and empirical cases when currencies become the same asset, Juli 2008

Nr. 75: Höhenberger, Nicole; Schmiedeberg, Claudia: Structural Convergence of European Countries, Juli 2008

Nr. 74: Nowak-Lehmann D., Felicitas; Vollmer, Sebastian; Martinez-Zarzoso, Inmaculada: Does Comparative Advantage Make Countries Competitive? A Comparison of China and Mexico, Juli 2008

Nr. 73: Fendel, Ralf; Lis, Eliza M.; Rülke, Jan-Christoph: Does the Financial Market Believe in the Phillips Curve? - Evidence from the G7 countries, Mai 2008

Nr. 72: Hafner, Kurt A.: Agglomeration Economies and Clustering - Evidence from German Firms, Mai 2008

Nr. 71: Pegels, Anna: Die Rolle des Humankapitals bei der Technologieübertragung in Entwicklungsländer, April 2008

Nr. 70: Grimm, Michael; Klasen, Stephan: Geography vs. Institutions at the Village Level, Februar 2008

Nr. 69: Van der Berg, Servaas: How effective are poor schools? Poverty and educational outcomes in South Africa, Januar 2008

Nr. 68: Kühl, Michael: Cointegration in the Foreign Exchange Market and Market Efficiency since the Introduction of the Euro: Evidence based on bivariate Cointegration Analyses, Oktober 2007

Nr. 67: Hess, Sebastian; Cramon-Taubadel, Stephan von: Assessing General and Partial Equilibrium Simulations of Doha Round Outcomes using Meta-Analysis, August 2007

Nr. 66: Eckel, Carsten: International Trade and Retailing: Diversity versus Accessibility and the Creation of "Retail Deserts", August 2007

Nr. 65: Stoschek, Barbara: The Political Economy of Enviromental Regulations and Industry Compensation, Juni 2007

Nr. 64: Martinez-Zarzoso, Inmaculada; Nowak-Lehmann D., Felicitas; Vollmer, Sebastian: The Log of Gravity Revisited, Juni 2007

Nr. 63: Gundel, Sebastian: Declining Export Prices due to Increased Competition from NIC Evidence from Germany and the CEEC, April 2007

Nr. 62: Wilckens, Sebastian: Should WTO Dispute Settlement Be Subsidized?, April 2007

Nr.61: Schöller, Deborah: Service Offshoring: A Challenge for Employment? Evidence from Germany, April 2007

Nr. 60: Janeba, Eckhard: Exports, Unemployment and the Welfare State, März 2007

Nr. 59: Lambsdoff, Johann Graf; Nell, Mathias: Fighting Corruption with Asymmetric Penalties and Leniency, Februar 2007 
Nr. 58: Köller, Mareike: Unterschiedliche Direktinvestitionen in Irland - Eine theoriegestützte Analyse, August 2006

Nr. 57: Entorf, Horst; Lauk, Martina: Peer Effects, Social Multipliers and Migrants at School: An International Comparison, März 2007 (revidierte Fassung von Juli 2006)

Nr. 56: Görlich, Dennis; Trebesch, Christoph: Mass Migration and Seasonality Evidence on Moldova's Labour Exodus, Mai 2006

Nr. 55: Brandmeier, Michael: Reasons for Real Appreciation in Central Europe, Mai 2006

Nr. 54: Martínez-Zarzoso, Inmaculada; Nowak-Lehmann D., Felicitas: Is Distance a Good Proxy for Transport Costs? The Case of Competing Transport Modes, Mai 2006

Nr. 53: Ahrens, Joachim; Ohr, Renate; Zeddies, Götz: Enhanced Cooperation in an Enlarged EU, April 2006

Nr. 52: Stöwhase, Sven: Discrete Investment and Tax Competition when Firms shift Profits, April 2006

Nr. 51: Pelzer, Gesa: Darstellung der Beschäftigungseffekte von Exporten anhand einer InputOutput-Analyse, April 2006

Nr. 50: Elschner, Christina; Schwager, Robert: A Simulation Method to Measure the Tax Burden on Highly Skilled Manpower, März 2006

Nr. 49: Gaertner, Wulf; Xu, Yongsheng: A New Measure of the Standard of Living Based on Functionings, Oktober 2005

Nr. 48: Rincke, Johannes; Schwager, Robert: Skills, Social Mobility, and the Support for the Welfare State, September 2005

Nr. 47: Bose, Niloy; Neumann, Rebecca: Explaining the Trend and the Diversity in the Evolution of the Stock Market, Juli 2005

Nr. 46: Kleinert, Jörn; Toubal, Farid: Gravity for FDI, Juni 2005

Nr. 45: Eckel, Carsten: International Trade, Flexible Manufacturing and Outsourcing, Mai 2005

Nr. 44: Hafner, Kurt A.: International Patent Pattern and Technology Diffusion, Mai 2005

Nr. 43: Nowak-Lehmann D., Felicitas; Herzer, Dierk; Martínez-Zarzoso, Inmaculada; Vollmer, Sebastian: Turkey and the Ankara Treaty of 1963: What can Trade Integration Do for Turkish Exports, Mai 2005

Nr. 42: Südekum, Jens: Does the Home Market Effect Arise in a Three-Country Model?, April 2005

Nr. 41: Carlberg, Michael: International Monetary Policy Coordination, April 2005

Nr. 40: Herzog, Bodo: Why do bigger countries have more problems with the Stability and Growth Pact?, April 2005

Nr. 39: Marouani, Mohamed A.: The Impact of the Mulitfiber Agreement Phaseout on Unemployment in Tunisia: a Prospective Dynamic Analysis, Januar 2005

Nr. 38: Bauer, Philipp; Riphahn, Regina T.: Heterogeneity in the Intergenerational Transmission of Educational Attainment: Evidence from Switzerland on Natives and Second Generation Immigrants, Januar 2005

Nr. 37: Büttner, Thiess: The Incentive Effect of Fiscal Equalization Transfers on Tax Policy, Januar 2005

Nr. 36: Feuerstein, Switgard; Grimm, Oliver: On the Credibility of Currency Boards, Oktober 2004

Nr. 35: Michaelis, Jochen; Minich, Heike: Inflationsdifferenzen im Euroraum - eine Bestandsaufnahme, Oktober 2004

Nr. 34: Neary, J. Peter: Cross-Border Mergers as Instruments of Comparative Advantage, Juli 2004

Nr. 33: Bjorvatn, Kjetil; Cappelen, Alexander W.: Globalisation, inequality and redistribution, Juli 2004 
Nr. 32: Stremmel, Dennis: Geistige Eigentumsrechte im Welthandel: Stellt das TRIPs-Abkommen ein Protektionsinstrument der Industrieländer dar?, Juli 2004

Nr. 31: Hafner, Kurt: Industrial Agglomeration and Economic Development, Juni 2004

Nr. 30: Martinez-Zarzoso, Inmaculada; Nowak-Lehmann D., Felicitas: MERCOSUR-European Union Trade: How Important is EU Trade Liberalisation for MERCOSUR's Exports?, Juni 2004

Nr. 29: Birk, Angela; Michaelis, Jochen: Employment- and Growth Effects of Tax Reforms, Juni 2004

Nr. 28: Broll, Udo; Hansen, Sabine: Labour Demand and Exchange Rate Volatility, Juni 2004

Nr. 27: Bofinger, Peter; Mayer, Eric: Monetary and Fiscal Policy Interaction in the Euro Area with different assumptions on the Phillips curve, Juni 2004

Nr. 26: Torlak, Elvisa: Foreign Direct Investment, Technology Transfer and Productivity Growth in Transition Countries, Juni 2004

Nr. 25: Lorz, Oliver; Willmann, Gerald: On the Endogenous Allocation of Decision Powers in Federal Structures, Juni 2004

Nr. 24: Felbermayr, Gabriel J.: Specialization on a Technologically Stagnant Sector Need Not Be Bad for Growth, Juni 2004

Nr. 23: Carlberg, Michael: Monetary and Fiscal Policy Interactions in the Euro Area, Juni 2004

Nr. 22: Stähler, Frank: Market Entry and Foreign Direct Investment, Januar 2004

Nr. 21: Bester, Helmut; Konrad, Kai A.: Easy Targets and the Timing of Conflict, Dezember 2003

Nr. 20: Eckel, Carsten: Does globalization lead to specialization, November 2003

Nr. 19: Ohr, Renate; Schmidt, André: Der Stabilitäts- und Wachstumspakt im Zielkonflikt zwischen fiskalischer Flexibilität und Glaubwürdigkeit: Ein Reform-ansatz unter Berücksichtigung konstitutionen- und institutionenökonomischer Aspekte, August 2003

Nr. 18: Ruehmann, Peter: Der deutsche Arbeitsmarkt: Fehlentwicklungen, Ursachen und Reformansätze, August 2003

Nr. 17: Suedekum, Jens: Subsidizing Education in the Economic Periphery: Another Pitfall of Regional Policies?, Januar 2003

Nr. 16: Graf Lambsdorff, Johann; Schinke, Michael: Non-Benevolent Central Banks, Dezember 2002

Nr. 15: Ziltener, Patrick: Wirtschaftliche Effekte des EU-Binnenmarktprogramms, November 2002

Nr. 14: Haufler, Andreas; Wooton, Ian: Regional Tax Coordination and Foreign Direct Investment, November 2001

Nr. 13: Schmidt, André: Non-Competition Factors in the European Competition Policy: The Necessity of Institutional Reforms, August 2001

Nr. 12: Lewis, Mervyn K.: Risk Management in Public Private Partnerships, Juni 2001

Nr. 11: Haaland, Jan I.; Wooton, Ian: Multinational Firms: Easy Come, Easy Go?, Mai 2001

Nr. 10: Wilkens, Ingrid: Flexibilisierung der Arbeit in den Niederlanden: Die Entwicklung atypischer Beschäftigung unter Berücksichtigung der Frauenerwerbstätigkeit, Januar 2001

Nr. 9: Graf Lambsdorff, Johann: How Corruption in Government Affects Public Welfare - A Review of Theories, Januar 2001

Nr. 8: $\quad$ Angermüller, Niels-Olaf: Währungskrisenmodelle aus neuerer Sicht, Oktober 2000

Nr. 7: $\quad$ Nowak-Lehmann, Felicitas: Was there Endogenous Growth in Chile (1960-1998)? A Test of the AK model, Oktober 2000

Nr. 6: Lunn, John; Steen, Todd P.: The Heterogeneity of Self-Employment: The Example of Asians in the United States, Juli 2000 
Nr. 5: Güßefeldt, Jörg; Streit, Clemens: Disparitäten regionalwirtschaftlicher Entwicklung in der EU, Mai 2000

Nr. 4: Haufler, Andreas: Corporate Taxation, Profit Shifting, and the Efficiency of Public Input Provision, 1999

Nr. 3: Rühmann, Peter: European Monetary Union and National Labour Markets, September 1999

Nr. 2: Jarchow, Hans-Joachim: Eine offene Volkswirtschaft unter Berücksichtigung des Aktienmarktes, 1999

Nr. 1: Padoa-Schioppa, Tommaso: Reflections on the Globalization and the Europeanization of the Economy, Juni 1999

Alle bisher erschienenen Diskussionspapiere zum Download finden Sie im Internet unter: http://www.uni-goettingen.de/de/60920.html. 